\title{
Iraqi Refugees: \\ Seeking Stability in Syria and Jordan
}

Patricia Weiss Fagen

Institute for the Study of International Migration

Georgetown University

and

Center for International and Regional Studies

Georgetown University School of Foreign Service in Qatar

(C) 2007, 2009 


\title{
Iraqi Refugees: Seeking Stability in Syria and Jordan
}

\author{
Patricia Weiss Fagen
}

\section{Fieldwork:}

Patricia Weiss Fagen, Senior Associate, ISIM

Sameer Jarrah, Director, Arab World Center for Democratic Development, Amman

(C) 2007, 2009 Center for International and Regional Studies Georgetown University School of Foreign Service in Qatar 


\section{A Study Co-Sponsored by:}

\section{ISIM \\ Institute for the Study of International Migration}

The Institute for the Study of International Migration (ISIM), founded in 1998, is part of the Edmund A. Walsh School of Foreign Service and affiliated with the Law Center at Georgetown University. ISIM focuses on all aspects of international migration, including the causes of and potential responses to population movements, immigration and refugee law and policy, comparative migration studies, the integration of immigrants into their host societies, and the effects of international migration on social, economic, demographic, foreign policy and national security concerns. ISIM also studies internal displacement, with particular attention to the forced movements of people for reasons that would make them refugees if they crossed an international border.

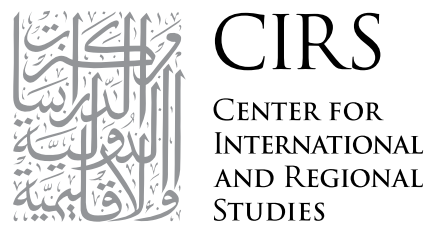

GEORGETOWN UNIVERSITY

SCHOOL OF FOREIGN SERVICE IN QATAR

Established in 2005, the Center for International and Regional Studies at the Georgetown University School of Foreign Service in Qatar is a premier research institute devoted to the academic study of regional and international issues through dialogue and exchange of ideas, research and scholarship, and engagement with national and international scholars, opinion makers, practitioners and activists.

Guided by the principles of academic excellence, forward vision, and community engagement, the Center's mission revolves around five principal goals:

- To provide a forum for scholarship and research on international and regional affairs

- To encourage in-depth examination and exchange of ideas

- To foster thoughtful dialogue among students, scholars and practitioners of international affairs

- To facilitate the free flow of ideas and knowledge through publishing the products of its research, sponsoring conferences and seminars, and holding workshops designed to explore the complexities of the twenty-first century

- To engage in outreach activities with a wide range of local, regional and international partners. 


\section{Iraqi Refugees: Seeking Stability in Syria and Jordan}

\section{Patricia Weiss Fagen}

Patricia Weiss Fagen, Senior Associate, works on ISIM's projects related to postconflict reintegration and reconstruction. She joined the United Nations High Commissioner for Refugees in 1988, and served in Washington DC as External Relations officer and from 1991-1993 as the Chief of Mission in El Salvador. During 1995-96 she was on loan to the UN Research Institute for Social Development, as senior associate of the War Torn Societies Project, and from 1996-98 she worked in the Economic Development Institute of the World Bank. Throughout this period, she specialized in research and operational projects related to post-conflict reintegration and reconstruction. From 1998-99, she worked in the Inter American Development Bank. She has also worked for the Refugee Policy Group, the Inter American Commission for Human Rights, and the Center for International Policy. She served for six years on the Board of Directors and Executive Committee of Amnesty International, USA.

Dr. Fagen has a Ph.D. from Stanford University, and has published a number of works related to Latin American history, human rights law and policy, political asylum and refugee issues, and post-conflict reconstruction.

This publication series is made possible by the generous support of Qatar Foundation for Education, Science and Community Development. 



\section{Foreword}

Over two million Iraqis are refugees in the Middle East, living in difficult conditions, primarily in Jordan and Syria. Their unresolved plight and their still largely unmet needs constitute a humanitarian crisis. Their presence has had an impact on the two countries where they are concentrated and, by extension, on the region as a whole. Although long hosts to Palestinian refugees, the countries of the Arab Middle East have not been major refugee destinations in recent decades and this report raises questions about the limited regional response to a major refugee flow. At this point, most Iraqis and their hosts hope for a quick and peaceful end to the insecurity that has precipitated the flight, but events in Iraq raise serious doubts that their hopes will soon be fulfilled. Some Iraqis are hoping for resettlement in the United States and other countries of the west, a hope thus far available only to a very few. The report raises questions about the apparently limited ability of the US and other countries to mobilize a major resettlement effort similar to those that took place during the Cold War. More fundamental to the lives of the vast majority of the Iraqi refugees, it calls on the international community to launch a more robust humanitarian response that will assist and protect the Iraqi refugees while addressing the legitimate economic, political and security concerns of Jordan and Syria as hosts to such large numbers of refugees.

This project represents a collaboration between two centers in the Georgetown University School of Foreign Service - the Center for International and Regional Studies, CIRS, located in Qatar and the Institute for the Study of International Migration, ISIM, in Washington. Each brings its own expertise to this examination of the Iraqi refugee crisis-CIRS on the regional dynamics and ISIM on the humanitarian issues. The primary author, Patricia Weiss Fagen, Senior Associate at ISIM, has written extensively on refugee issues and, prior to joining Georgetown University, served as a Representative of the UN High Commissioner for Refugees.

CIRS and ISIM joined together in the belief that greater understanding of the full political, economic and humanitarian context in which the Iraqi refugee crisis is unfolding is needed as a precursor to more effective action on behalf of the refugees as well as the countries that are hosting them. We hope that this report spurs such action.

Mehran Kamrava

Director

CIRS

Susan Martin

Director

ISIM 


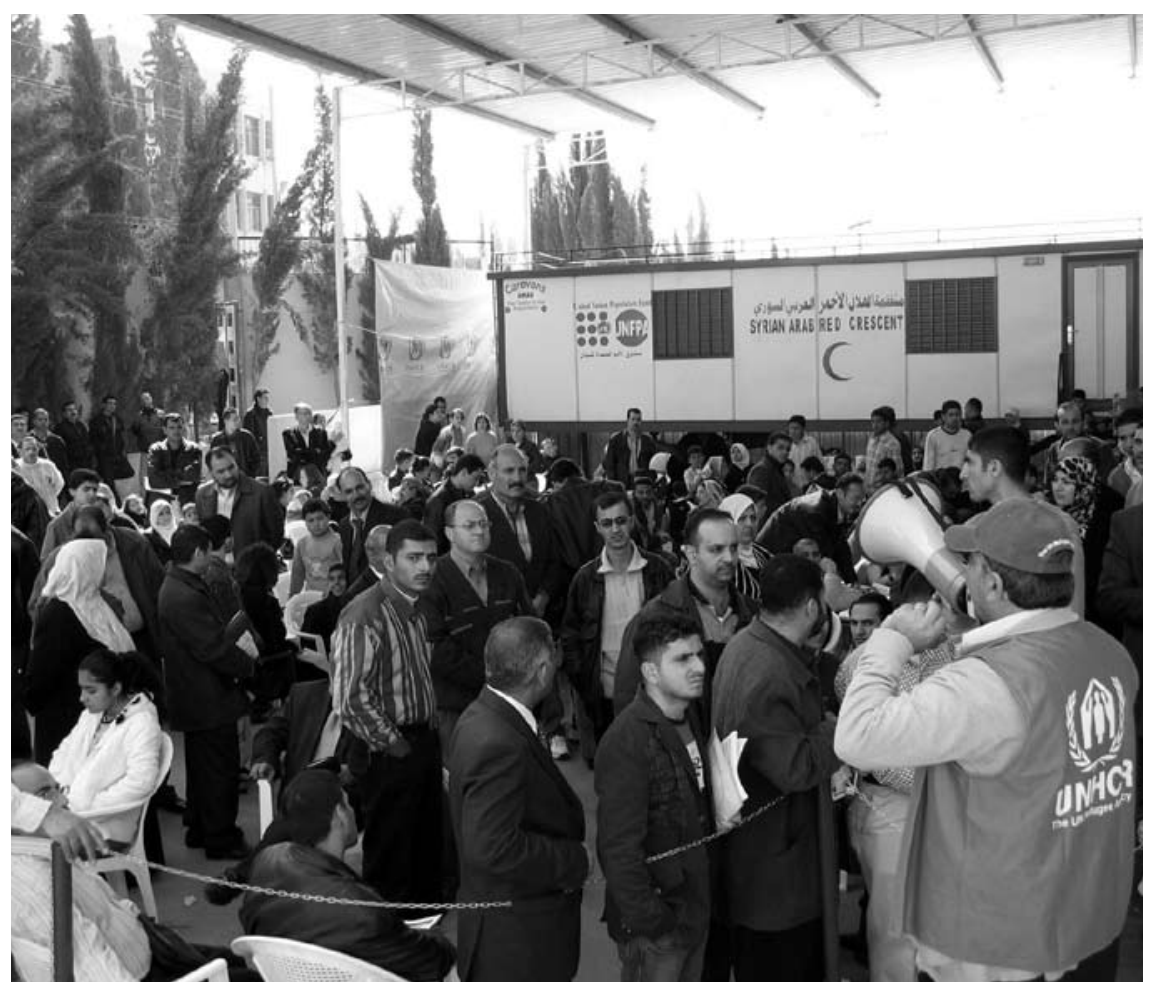

Fleeing Iraqis line up to register at the Duma UNHCR center in Syria in 2004 (Courtesy of UNHCR Syria). 
Over two million Iraqis have crossed borders during the past years to save their lives and livelihoods. The majority has found a safe refuge, albeit an increasingly difficult one, in two neighboring countries, Syria and Jordan. These two countries have kept their doors open to refugees long after other regional destinations were closed. That refuge, however, is close to exhausted as well because of resource strains, security concerns and the fact that violence in Iraq is continuing rather than abating. Meanwhile, the majority of Iraqis are in legal limbo in their host countries, tolerated but, more often than not, lacking documentation or authorization to work.

Iraqis in Jordan and Syria are beneficiaries of two conflicting policies: one is the tradition of Arab brotherhood which constitutes a political and moral imperative to provide refuge and the other is a determination on the part of both governments not to integrate the Iraqis or acknowledge their permanency. Officials in Jordan and Syria declare themselves committed to non refoulement until peace is re-established in Iraq. In the meantime, the Iraqis are given refuge as guests, but not acknowledged as refugees for whom the state takes responsibility. The United Nations High Commissioner for Refugees, UNHCR, deems the Iraqis to be prima facie refugees; those who register receive asylum seeker cards in Jordan and refugee cards in Syria. UN agencies and NGOs provide humanitarian assistance that alleviates suffering but is far from meeting urgent needs.

The Iraqis are concentrated largely in Amman and Damascus, the capital cities of Jordan and Syria respectively. Their massive presence has affected local residents in mostly negative ways. Citizens blame the Iraqis for rising prices of real estate, rent and food; for overcrowded schools and health facilities and for shortages of electricity and water. As the report shows, Iraqis are neither the sole cause of the rising prices, nor are they a net drain on the two countries' economies. Nevertheless, resources and services normally available to citizens are presently seriously stretched.

The international response to this major humanitarian crisis has been tepid. Regional governments outside of Jordan and Syria have neither welcomed Iraqis within their borders, nor supported Jordanian and Syrian efforts to meet the needs of the expanded population. Western donors have mobilized funding in modest amounts, and have channeled most of it through international organizations and the Red Crescent societies. While the traditional resettlement countries are increasing the numbers of Iraqis they are willing to take, the numbers remain very small. The United States bears the major responsibility for the plight of the Iraqis and leads in resettlement numbers, but the few thousand who will be absorbed represent a tiny fraction of those who wish to apply. To be sure, most Iraqis and their hosts would prefer successful efforts to establish peace in Iraq, thus permitting people to return rather than becoming permanent refugees. 


\section{Introduction}

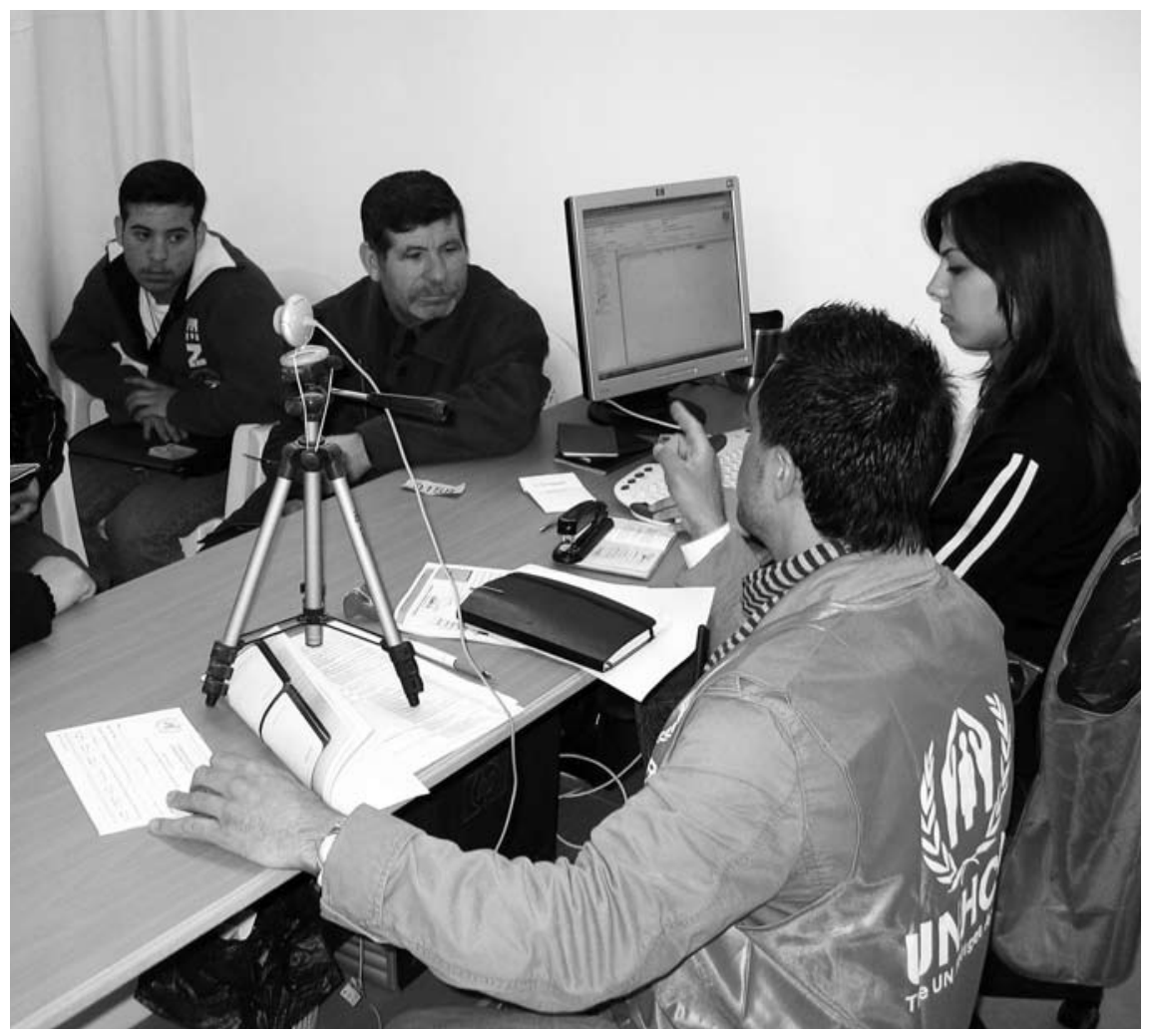

An Iraqi family registers as refugees at a Syrian UNHCR Office in 2004 (Courtesy of UNHCR Syria).

The war in Iraq is not limited to Iraq. It has been exported in many forms and has profoundly affected dynamics throughout the Middle East region. US occupation and ethnic conflict among Iraqis ended the dominance of the minority Sunnis who previously controlled the government and shifted it to the Shi'ite majority who predominate in the present government. This shift is worrisome to Iraq's neighboring majority Sunni countries. It is particularly worrisome because, as so often occurs, the conflict has enhanced the power of extremists and fundamentalists in Iraq and all but eliminated the spaces available to advocates of tolerance and co-existence. Home grown fundamentalists in other countries take heart. Of particular concern in the region and outside of it, the political struggle in Iraq has enhanced the influence of its former enemy, Iran, which is now a major power broker. Terrorist organizations, especially Al Qaeda, formerly absent from Iraq, have also been able to take advantage of the chaotic and violent conditions and to establish a significant presence there. The neighboring countries are worried that as terrorists increase their foothold in Iraq, they will cross borders. 
The most visible effects of the war in Iraq are the human consequences of pervasive violence. The humanitarian crisis facing Iraqi civilians is of monumental proportions. News releases throughout the world report military confrontations and, more often, daily attacks on ordinary people attempting to go about the business of surviving. Survivors, increasingly, flee. It is not the first time Iraqis have fled from war, but it is without doubt the most devastating instance with the most far-reaching impacts on Iraq and the region overall.

In many other parts of the world, the United States is able to exert a positive influence in brokering peace and responding to both security and humanitarian concerns. As the major party to the conflict, however, the capacity of the United States to play these roles in Iraq has been seriously compromised. This has left a significant gap in the international response to the unfolding humanitarian crisis in Iraq and its neighbors.

The current Iraqi displacement is the largest in the Middle East region since the flight of Palestinians in 1948 and already far surpasses it in numbers of people. To this day, the concept of "refugee" is largely reserved for Palestinians. Apart from a few hundred refugees and migrants mainly from Africa, the Palestinians still represent the giant share of the non-national population in Jordan and Syria. They have legal status, but lack citizenship in most of the region. ${ }^{1}$ Most have been refugees for three generations. Today, in the face of the very visible Iraqi presence and the obvious fact that they cannot return to their country, the Jordanian and Syrian authorities are reluctant to think of the new arrivals as refugees. One senses the concern on the part of the host country governments that designating Iraqis as refugees also implies acknowledging that Iraq will not recover political stability soon and its refugees may remain in these countries for the long term, as the Palestinians have.

Iraqi displacement has occurred with depressing frequency since the Iran-Iraq war of the 1980s. Iraqis in the opposition regularly sought refuge in Syria. During the Saddam Hussein years, they sought refuge most often in Jordan. Significant numbers of Iraqis went to neighboring countries in 1991 following the first Gulf War and, in many cases, remained there. The already existing ties and human relationships have facilitated the present movement.

Since the start of the conflict in 2003, and in increasing numbers since 2006, the Iraqis have fled from insurgents, former Baathists of the Saddam era, militias, occupation forces, criminals, and economic devastation. Over two million Iraqis have crossed borders during the past years to save their lives and livelihoods. As before, the majority has found a safe refuge, albeit a difficult one, in neighboring Syria and Jordan. Those two countries kept their doors open to refugees ${ }^{2}$ long after other regional destinations were closed. That refuge, however, is close to exhausted, primarily because of the sheer numbers of people but also because of concerns about security in the present context. The war continues to take its toll and drives people to flee, but at this writing, there are no longer viable outlets. The Iraqis who already have left, as will be described, are in legal limbo. The host countries have allowed them to enter and thereby to find relative security, but their lives are on hold. 
In addition to producing massive flight, the war in Iraq has profoundly affected political and economic relations throughout the Middle East. Trade relations have been severed and reformulated. Previous alliances have been broken and new alliances formed, to a large extent on ethnic bases. The chaotic conditions in Iraq enable extremism to flourish there and, potentially, to spread beyond. Security concerns are at the heart of regional policies toward Iraqi refugees.

This report builds on previous and ongoing accounts of the hardships the exiles have faced in their efforts to find safety. It focuses on the impacts the massive outflow of Iraqis has had on Jordan and Syria, the two countries that have received most of them. It is also about the broader international response to the tragedy, its weaknesses, and what can be expected.

The two field researchers who conducted the work combine regional expertise and extensive contacts in the target countries with knowledge of refugee, humanitarian and human rights law and practice. They spent approximately one week each in Jordan and Syria, where they interviewed government officials, UN officials, donors, independent experts and analysts and a few Iraqis in the two countries. The interviews listed in the appendix were in-depth inquiries, tailored to the specific functions, expertise, or operational roles of the informants. With few exceptions, all interviewees requested that we not attribute their statements and opinions. While their statements, therefore, are not cited, the information is attributed to the category to which they belong.

A thorough understanding of the situation facing the Iraqi refugees is fundamental to an analysis of their impact in their host countries. For this purpose, the researchers relied primarily on the fairly extensive and growing documentation about Iraqis' legal status, their basic needs, their fragile livelihoods and meager opportunities. ${ }^{3}$ The field-work was preceded by an extensive literature search that covered this literature as well as material about the respective host countries' policies and institutions. The researchers gathered additional documents in the course of the mission.

The authors found much to admire in the willingness of Jordan and Syria to host such large numbers of Iraqis - large in absolute numbers and in proportion to the Jordanian and Syrian population and economy. Treating the Iraqis as guests, not refugees, the two host countries have largely born the burden alone, a burden tempered by some positive impacts on the local economies. Alarmed, however, at the growing costs of hosting the Iraqis, Jordan has closed its border to future flows of Iraqis and Syria has announced its intention to restrict new movements. The international community has been slow to provide support and both Jordan and Syria have viewed international engagement with a measure of distrust. Now, however, with deteriorating conditions for the Iraqis already resident, pressures on host country institutions that are barely able to provide for citizens, and the prospect of closed borders, international assistance is urgently needed. As will be shown in this report, recognizing that there is indeed a refugee crisis is the first step towards finding solutions for the Iraqis and their hosts. 


\section{Causes of Flight}

In Iraq, the violence ebbs and flows from one region to another, but does not abate. Pervasive violence profoundly affects livelihoods for the entire population. A July 2007 study by the NGO Coordinating Committee and Oxfam International documented that, in addition to the physical insecurity, over 40 percent of the population is living in absolute poverty, and over half are without work. Larger numbers lack water, sanitation, electricity, education, and health care. Malnutrition is growing because families cannot feed themselves, and the ration system which operated prior to the war to assure Iraqis minimum food and necessities is largely broken. ${ }^{4}$ The middle class has been decimated and professionals and technocrats with the skills needed to build and maintain institutions and systems either have left or are unable to work due to violence or specific threats. ${ }^{5}$ The religious minorities in towns and cities, especially Baghdad, have been forced to abandon neighborhoods or communities where they have long lived. Political figures, judges, intellectuals, journalists, and anyone thought to be working with the occupying powers are likely targets of violence. The options are few and, for most Iraqis, unattractive.

For a short time after 2003, the Shi'ite south of Iraq was a relatively safe haven for Shi'a displaced from elsewhere, but there too divisive political and religious conflicts brought violence and produced displacement. The three northern governorates of Iraq have always been tense and subject to outbreaks, but were relatively safe destinations for those fleeing the far more violence prone areas. Now these governorates sharply restrict entries. There are few remaining safe destinations for internal displacement. ${ }^{6}$

Although Iraqis have been displaced by war and repression for decades, the present scale is unprecedented. The current flight began in the aftermath of 2003 as security deteriorated and ethnic conflict increased. Violence accelerated sharply after the bombing of the Sammara Al Askari Mosque in February 2006 and caused more widespread displacement. Departures during 2007 will surely surpass those of 2006. The mid 2007 calculations by the International Organization for Migration report close to 2.2 million Iraqis displaced within the borders of the state, while another approximately 2 million Iraqis had fled to neighboring countries. ${ }^{7}$ In midAugust, UNHCR sources were reporting Iraqi departures at 60,000 per month, most headed for Syria. ${ }^{8}$

\section{“Iraqis are Guests ...”}

In the airports and at border crossings, arriving passengers are separately channeled into lines marked for Arab countries and "foreigners," Although obviously foreign by legal definition, the nationals circulating among the countries considered in this report-Iraq, Jordan, Syria, and other Arab countries - are not considered "foreigners" in the same sense as somebody from Europe or the Americas. The "foreigners" may be better treated at border crossings and airports; nevertheless, the citizens of countries in the region are readily incorporated into the national 
fabric of their host countries: they purchase properties, establish businesses, invest funds and often settle for long periods of time. This tradition is especially strong in Syria. Visitors from neighboring Arab countries may send their children to schools, use health facilities, and buy properties and businesses.

While regional residents can move easily across borders, they do not thereby acquire legal status in the host countries. They enter as guests or tourists with temporary permits and have the possibility of renewing such permits over the years, sometimes over decades. Work authorizations are given selectively but, while employment usually brings longer term residence permits, it does not change the individual's legal status. Present law in most Arab countries makes it difficult for anybody to acquire permanent status or citizenship, no matter what their reasons for being in the country or how long they have stayed there. Children born of parents from neighboring countries continue to hold the citizenship of their families and not their birthplaces. ${ }^{9}$ Obviously, the difficulty in obtaining legal status - much less nationality - poses problems for refugees who cannot avail themselves of citizen rights in their home countries.

The Iraqis already in exile have been accommodated as "guests" within this framework. While the outside world considers them to be "refugees," they have no corresponding status in their host countries. Present regional havens include Syria, Jordan, Egypt, Lebanon, Kuwait, and small numbers in Iran, the Gulf States and Turkey. ${ }^{10}$ Of these, only Egypt and Turkey have signed the UNHCR refugee Convention - with heavy restrictions and limited effective protection. ${ }^{11} \mathrm{~A}$ November 2006 Human Rights Watch report stated, "generally, Iraqis throughout the Middle East remain unregistered, uncounted, unassisted and unprotected." 12 Over the past year, awareness has grown and humanitarian responses for Iraqis have improved, but their status is no different.

The Iraqis are beneficiaries or victims of two conflicting policies. On the one hand, the tradition of "Arab brotherhood" provides a political and moral imperative to accept Iraqis in need of refuge; on the other, a strong determination not to establish arrangements that might lead to permanence deters the host countries from offering a more secure refuge. Neither the government of Jordan nor Syria is anticipating or preparing for a long-term Iraqi presence. Nor, indeed, do most of the Iraqis wish for this outcome, at least not at the present time. Nevertheless, all officials in Jordan and Syria affirm their commitment to shelter the Iraqi guests until a return is made possible by a peaceful resolution of civil strife in Iraq. In both countries, officials expressed their belief that eventually Iraq would "calm down." In reality, few seriously expect the Iraqis to be able to return in large numbers any time soon. To the contrary, all recognize, first, that the present situation in Iraq is worsening and continues to produce more displacement and, second, that war and displacement threaten regional security.

UNHCR is very much present in the host countries, and that agency has the lead role in managing the humanitarian programs related to Iraqis. It has been able to offer services and some protection, and has successfully mobilized donor funding for its work. UNHCR's ability to protect the Iraqi refugee population is problematic because of the latter's status - or lack thereof - and the fact that the governments have not signed the Refugee Convention. The Syrian government 
accepts the UNHCR designation of prima facie refugees for the Iraqis; the Jordanian government does not. The differences in practice are insignificant. The premise with regard to Iraqis in both countries is the same: a temporary haven pending return.

The ability of UNHCR and other agencies to assist Iraqis in Jordan and Syria is especially difficult because they are heavily concentrated in the respective capital cities, Amman and Damascus. No current refugee population in the world is so heavily concentrated in major cities, living among the local population. Similarly, no current unrecognized refugee population has had as strong an impact on the lives of citizens in the countries where they have taken refuge.

\section{Jordan and the Iraqis \\ Legacy of Migration and Economic Ties}

To better grasp Jordanian sensitivities, it is useful to go back to the migration that precedes the present Iraqi flight. Over 900,000 Palestinians were displaced in the conflicts that accompanied the creation of the state of Israel and found themselves living in the neighboring countries or on land occupied by Israel. ${ }^{13}$ They were welcomed primarily in Jordan, and in smaller numbers in Syria, Iraq, Lebanon and Egypt with an assumption that they would soon return to their homes. Instead, today, there are more than seven million Palestinian refugees and displaced persons in the region (now including Gulf States), with varying forms of status and assistance. ${ }^{14}$ They are still awaiting the resolution of their situation and insisting on their right to return. But it is widely believed that the majority will probably remain in the countries where they now find themselves, especially those well established in Jordan. In most of the region, Palestinians have depended in large part on assistance from the United Nations Relief and Works Agency, UNRWA, which began operations in 1950. In Jordan, however, the West Bank Palestinians displaced in 1948 and 1967 arrived in the country holding Jordanian passports. ${ }^{15}$ Half or more of the just under six million Jordanians are of Palestinian origin. ${ }^{16}$ It is a sensitive point for many Jordanians, and unquestionably colors their receptivity to Iraqis.

The pre-war relations between Jordan and Iraq were positive, especially in economic terms. During the 1980s Iraq and Jordan were major trading partners and Iraq was the major market for Jordanian exports. ${ }^{17}$ During the Saddam Hussein regime, Jordan received highly subsidized oil from Iraq-especially after sanctions were imposed on Iraq. Jordan's population is overwhelmingly Sunni and there are close tribal ties between the two countries. Jordan politically supported Iraq in the first Gulf War. Present relations are more problematic due to Shi'ite political dominance coupled with growing Iranian influence in Iraq, which Jordan perceives as potentially threatening.

Regardless of political affiliations, wealthy Iraqis of all ethnicities have invested in Jordan over the years as a hedge against instability and repression in their own country, and often acquired properties there. Dissidents of Saddam Hussein's government found a safe refuge in Jordan. Following the US invasion 
in 2003, direct trade relations declined sharply, and Shi' ite political power ended the Sunni political hegemony in Iraq. Still, large numbers of the wealthier Iraqis physically displaced themselves to Jordan to live, having already invested their funds. The earlier migrants to Jordan following the 2003 US invasion of Iraq were more likely to be Sunnis. But, as violence accelerated in Iraq, Shi'ite migrants, many of whom also had financial interests in Jordan and resources to invest, joined the flight. Iraqis with financial means have been absorbed in Amman insofar as they have acquired property, businesses, and jobs. Jordanians typically perceive Iraqis as wealthy property owners, and the characterization is not without foundation.

\section{Numbers}

At the outset of this research, informants in and out of government maintained that Jordan was hosting between 700,000 and 800,000, and possibly more, Iraqis. The numbers, presumably, are not changing because for nearly a year the border has essentially been closed. Officials monitored entries, at least after 2003, but exits are not monitored; nor is there an accurate count of the pre-war Iraqi population residing part-time or full-time in Jordan. It is undeniably important for the government to learn about the Iraqi population living within its borders, how many there are, where they are, what resources they bring and the needs they have. Without such information, neither national nor international efforts to address the needs of the Iraqis and the host population can be appropriately planned and funded.

In the interest of achieving greater clarity, the Jordanian Foreign Ministry and Department of Statistics contracted a Norwegian based organization, Fafo to undertake a household study of the population.Fafo has a Middle East regional office in Jordan and in 2000 did a survey for Jordan on camp conditions for Palestinian refugees. The Iraqi refugee survey should include statistics on Jordanians as well, and to result in a report covering numbers, geographical distribution and demographic characteristics. Importantly, the study also promised to assess the Iraqis' impact on the Jordanian economy and the added costs of providing public services to them. ${ }^{18}$

In April and May, 2007, Fafo researchers completed the field-work, but at this writing, the report has not been published. Individuals in the government and outside who say they have seen the results claim the Fafo totals show just over 400,000 Iraqis in Jordan. They also say the report will be modified before it is released (in September or October) and will focus more on demographics than total numbers - the implication being that the government had problems with the numbers. Those who criticize the (unseen) results make a persuasive case about flaws in the methodology, flaws which are not necessarily the fault of the researchers. First, the last census in Jordan was carried out in 2004. Obviously the number of Iraqis counted at the time of that census is well under the present total. Second, a large portion, if not the majority of the Iraqi population is residing in Jordan without legal status. Like undocumented immigrants everywhere, the Iraqis can be assumed to be reluctant to identify themselves to survey takers. This being 
the case, Iraqis are unlikely to come forward and be counted so long as the present Jordanian policy remains in effect. Unless and until the Jordanian government moves from unofficial toleration of Iraqi residents without documentation to some mechanism that permits Iraqis to regularize their status, many will hide from the census takers.

\section{Acquiring Legal Status in Jordan}

The Iraqis who have done well in Jordan are those who have been able to take advantage of the Jordanian regulations encouraging investments and offering tax exemptions for the investors in sectors deemed beneficial to the economy. The beneficial investments may include hotels, hospitals, agricultural and urban infrastructure and other businesses. Iraqis with resources to invest have undertaken projects with generous terms, and have become important and very visible business owners and property holders. Importantly, investments in business and/or employment in jobs deemed economically important to Jordan - such as university professors - not only ensure livelihoods but also provide a path to legal status based on yearly, renewable, residence permits. ${ }^{19}$ Only those Iraqis able to invest in Jordanian enterprises or who are employed in fields deemed to be of national interest have been able to obtain long-term status. The investment entitles them to receive yearly residence permits, to seek employment in specified fields, send their children to schools and access public services.

The Iraqis who do not have funds to invest, who constitute the majority, have faced hardships. Foreigners entering the country who do not invest in enterprises must show they are able to support themselves in order to obtain and renew residence permits. This means they are required to deposit close to US $\$ 150,000$ in a Jordanian bank, and must maintain a sufficient balance (about half) to earn interest. ${ }^{20} \mathrm{With}$ time, many of the families who arrived with some wealth but were unable to invest in income generating businesses or obtain professional positions have exhausted their savings and have been impoverished. While no firm figures are available, it is fair to say a large portion of the present Iraqi population lacks investment property, jobs and legal status in Jordan and has grown increasingly poorer. By all accounts, the situation of these less affluent Iraqis ranges from very difficult to dire.

Until the end of 2005, virtually all Iraqis were allowed into the country and were able to register as guests, or visitors, for a period of three to six months, without work authorization. The temporary residency permits they received were subject to renewal, but as renewal became more difficult after 2005, the numbers of unregistered Iraqis increased. The single most important event in the policy shift toward tighter security and enforcement occurred in November 2005 when thirteen Iraqi terrorists associated with $\mathrm{Al}$ Qaeda threw bombs into three luxury hotels, and among those killed were several guests at a Jordanian wedding. Other terrorist cells with Iraqi links have been identified (and dismantled) in Jordan. After the attacks of November 2005, renewing permits became far more difficult. Meanwhile, the Iraqi internal conflict intensified after the bombing of the Mosque at Sammara in February 2006. Thus, as Jordanian authorities justified limiting access to Iraqis on security grounds, the population seeking to leave Iraq grew larger, more diverse and poorer. 
In 2006 Jordan was excluding single men and boys between 17 and 35 from entering; then it began insisting that Iraqis produce a newly issued passport, which very few could obtain. Finally in 2007, the border was acknowledged to be closed except for exceptional cases. It remains essentially closed at this writing.

The Jordanian government has repeatedly affirmed its formal commitment to non-refoulement, having signed a Memorandum of Understanding with UNHCR in 1998 affirming that principle. Jordanian authorities defend their policies as being flexible and responsive to humanitarian and political considerations. In other words, they classify Iraqis as guests, subject to rules governing other nonJordanian nationals; but Iraqis are understood to be politically endangered in their home country. ${ }^{21}$ Jordanian authorities, in principle, do not send Iraqis back to their places of origin; they do not collect the fines from Iraqis that, by law, undocumented residents are supposed to pay for each day they overstay (unless the Iraqis in question leave the country or commit an infraction). In any number of instances, Jordanians have bent the rules to accommodate particular Iraqis and their needs. Nevertheless the Jordanian policy of humanitarian flexibility is double edged in practice. It allows different authorities to interpret the regulations differently, which opens the way to frequent abuse against the Iraqi population. Iraqis have been rejected at the border or expelled from the country with no clear explanations as to why, they have been treated with discrimination and-principles notwithstanding - many have been sent back to Iraq. ${ }^{22}$

Being undocumented, as most Iraqis in Jordan are at the present time, has precluded them not only from most forms of gainful employment but, until recently, severely restricted their access to public services. Most egregious was the regulation in effect until August 2007 that the children of unregistered residents could not attend public schools.

\section{Iraqis and Refugee Status}

For UNHCR, Iraqis from south and central Iraq meet the definition of prima facie refugees, (persons fleeing generalized violence and persecution), and it undertook to register them as such after 2003. Registration allows UNHCR to identify Iraqis in need of protection, offer assistance and vet them for the few resettlement opportunities available. As noted, the Jordanian government refused to accept the prima facie designation. Instead, it insisted on going back to the terms of a 1998 Memorandum of Understanding stating that persons registered with UNHCR, including Iraqis, would be designated as asylum seekers rather than given prima facie refugee status. Accordingly, UNHCR now gives documentation identifying Iraqis who come forward as asylum seekers. The "asylum seeker" status implies a smaller claim on protection than does prime facie refugee status, but it is not at all clear that UNHCR's protection role would have been significantly enhanced had the government accepted the latter.

Among the Iraqis registered with UNHCR, a small percent is presented to resettlement countries. Registration is ongoing, and at a rapidly increasingly pace over the past year. At this writing about 45,000 Iraqis have been registered, which 
is but a fraction of the lowest estimates of Iraqis in Jordan. The small response to the offer of asylum seeker cards may be related to the UNHCR's location far from the downtown centers of Iraqi settlement. However, there is also reluctance among Iraqis to come forward and be registered. Correctly or incorrectly, most of those whose legal status has expired, reportedly fear being identified and deported, and/ or they fear negative reactions from fellow Iraqis who do not want to be identified as refugees. In the Iraqi community hopes for return are still high, and becoming a refugee is widely seen as giving up those hopes. Finally, the asylum card does not offer major advantages in the Jordanian context.

Jordanian officials as well as international observers concur that the country needs to establish clearer guidelines for the legal status and economic rights of the Iraqis, however they are classified. It is also important to ascertain the size and composition of the Iraqi population. Until this is done, the system will be open to abuses and misinformation. This is the purpose of the much-awaited Fafo report.

\section{The Assistance Regime}

A large number of UN agencies, and local and international NGOs are based in Jordan. In fact, the NGO presence in Jordan and elsewhere in the Middle East is longstanding, having been created decades ago to address Palestinian refugee needs. Many programs were established in the relative safety of Amman after the 2003 invasion with the intention of serving the Iraqis in Iraq. As the refugee population grew, several organizations shifted to, or added Jordanian components. NGOs have been operating humanitarian programs for vulnerable groups and poor families, targeted at both country nationals and Iraqis. They have established projects in neighborhoods where Iraqis are especially prominent and variously deliver food aid, funds for school fees, health care, and community improvement efforts. UNHCR, which is the major humanitarian assistance organization, provides services directly, through NGOs and through the government with programs for food and cash assistance, health, community services, education, SGBV and legal assistance. Working with UNHCR are the Jordanian government Ministry of Planning and International Cooperation, the Jordanian Red Crescent, the Jordan Women's Union, Mizan, and the Jordanian Alliance against Hunger. A number of international humanitarian NGOs also operate in Jordan, including Mercy Corps, Care International, Caritas Terre des Hommes and Save the Children. The various projects are primarily targeted at Iraqis, but include Jordanians as well.

UNHCR has had a somewhat rocky relationship with the Jordanian government although all parties agree that the relationship has improved considerably. Other UN agencies (UNICEF, WFP, UNFPA) likewise have established humanitarian programs for vulnerable nationals and Iraqis, as well as development projects, often in collaboration with the government. ${ }^{23}$ For the Iraqi population, however, the impact of assistance remains limited. International agencies express the desire and intention to do more and, to this end, are increasing humanitarian budgets channeled through international agencies. 
As international funds have been offered for Iraqi assistance, Jordanian officials have debated the terms under which they should be accepted and how they should be channeled. Along with Jordanian reluctance to apply or even use refugee terminology, the government has been cautious about international initiatives targeted for Iraqi assistance. The government still discourages donors from projects that establish a refugee category and is ambivalent with regard to an expanded UNHCR role based on donor funds for assistance activities. The worry is that assistance to Iraqis could give rise to parallel structures or programs that are not already Jordanian priorities, or to activities managed by non-Jordanian organizations..$^{24}$

The major international initiative in which Jordan is participating is a Joint UNHCR-UNICEF appeal to support the education of Iraqi children in Jordan, Syria, Egypt and Lebanon. ${ }^{25}$ The US government strongly urged this step. International human rights advocates and donors had been criticizing the fact that Iraqi children whose families were not registered were not permitted to enroll in public school. Some private schools remained open to anyone who could pay, but fewer and fewer Iraqi families could afford tuition. Jordanian officials countered that the government-supported schools could hardly absorb the children of its own citizens, and to accommodate the Iraqis would require the government to build additional schools, hire teachers and buy school materials of all kinds. Jordan's King Abdullah II proved to be key figure in deciding to reverse the exclusion. Accordingly, the Ministry of Education took the decision, on humanitarian grounds, that Iraqi students with or without residency permits could enroll in public schools as of the school year beginning on August 19, $2007 .{ }^{26}$

The cost implications of providing education to Iraqi children are enormous, and the funds from the international appeal will offer an important contribution to the country's absorptive capacity. Response to the appeal has been positive ${ }^{27}$ although few pledges have been finalized as of this writing. Jordan can expect to receive approximately $\$ 80$ million (The request is for $\$ 129$ million for the region as a whole). The funds will go through and be managed by government channels, and will improve an educational system that Jordanians value for themselves. The provisions of the appeal allow each country to use the funds according to its own priorities. Jordan will construct schools, renovate classrooms, and hire teachers among other activities. Funds will also be used to buy uniforms and supplies for Iraqi children. It should be noted, the agreed-upon estimate that the schools will need to absorb 50,000 Iraqi children is based on speculative demographic information.

Some progress can also be seen regarding international assistance for health services. Due to the breakdown of the health system in the country, combined with the injuries and psychological toll of the war, the Iraqis suffer from abnormally high levels of unmet health care needs. Although health care is available to all regardless of legal status or registration, officials in the Ministry of Health have acknowledged that few Iraqis thus far have availed themselves of the public services. Many who lack legal status in the country are probably fearful of being identified; but more important, the facilities and personnel are badly stretched, hence unresponsive, especially in poor neighborhoods where Iraqis live. ${ }^{28}$ Iraqis 
who could not afford private care sought health care, preferably, from small non government organization supported programs.

The World Health Organization (WHO) convened a meeting in Damascus at the end of July, 2007, where participants from the countries affected by Iraqi refugees agreed to discuss a common framework that would facilitate donor funding. Finally, on September 18, 2007, UNHCR, WHO, UNICEF, UNFPA and WFP launched an appeal for US $\$ 84.8$ Million to help host countries-primarily Jordan and Syria - meet health and nutrition needs of Iraqi refugees. Included are funds to support state run clinics and facilities, to purchase medicines and medical supplies and improve public services generally. ${ }^{29}$

Future projects with international funding are being promoted. It is possible that the Iraqi presence will spur long needed improvements in social services and international support for these. There have been discussions about improvements in health delivery, and very badly needed support for water infrastructure and distribution. Deteriorating water supplies have led to deteriorating health as well. Jordan is the most water-starved country in this dry region, and there are urban and rural neighborhoods where water supplies were dramatically inadequate even before the Iraqi entries.

\section{Iraqi Impacts, Perceptions and Realities}

Jordan's population is just under 6 million people. Whether the Iraqi influx is 700,000 plus or 400,000 , this number of people, crowded almost entirely in Amman, creates a significant impact. While there has been a slow movement of Iraqis out of Amman to Zarqa, Irbid, and other towns, Amman is still far and away the most heavily impacted. The impact is both positive and negative. It is a consequence of Iraqi wealth and Iraqi poverty; and it is felt directly or indirectly, by virtually all segments of Jordanian society, albeit especially by Amman residents.

Citizens in Amman typically cite the Iraqis as the reason for their own deteriorating quality of life, i.e. high prices, unavailable and prohibitively expensive housing, inflation, deteriorating public services and infrastructure, crime, and impossible traffic. The government subsidizes public services, and all the state bureaucracies - from property registration offices, to public safety units, to municipal water and sanitation administrations-have added personnel but complain of being unable to cope with the added work-load.

Public safety officers working in Amman affirm that while crime has increased for other reasons, the Iraqis have not created any particular security problems. Their work-load has increased because of the rising population, and policing duties at the borders have greatly increased as well, as one would expect in such circumstances.

Iraqis, as noted above, do not make large demands on public health facilities. They do, however, purchase very large quantities of Jordanian goods and services, and they employ Jordanian construction workers, doctors, concierges, technicians, etc. Their economic activity, especially in construction, boosts employment but, at the same time, Jordanians and Iraqis do compete for some jobs. 
Every Jordanian encountered in the research singled out the rapidly accelerating cost of housing and most blamed wealthy Iraqis for having purchased or rented available space. The amount of property currently in the hands of Iraqi investors and what it represents in national economic terms is controversial. The Ministry of Industry and Trade has recorded 4,616 registered Iraqi enterprises in Jordan and some $\$ 300,000$ million in Iraqi investment in 2005 and 2006. ${ }^{30}$ Such amounts have given rise to notions of Iraqi economic dominance. In fact, figures show that Jordanians themselves are by far the largest investors, and the major foreign investment comes from Saudi Arabia, Kuwait, and the United Arab Emirates, with Iraqis in fourth place. ${ }^{31}$ Newly wealthy nationals and investors from the Gulf states have participated to a greater extent than have Iraqi refugees in the real-estate boom that has so dramatically raised the prices of housing in Amman. ${ }^{32}$

The Iraqi influx is also blamed for the significant rise in inflation in Jordan. Here, the real situation proves to be complex. A recent study conducted by the Jordanian Center for Strategic Studies at the University of Jordan came to conclusions that surprised many of its readers. ${ }^{33}$ Inflation rose from $1.6 \%$ in 2003 to $6.5 \%$ in 2006 , coinciding with the Iraqi influx. However it was driven primarily by food prices, which have risen $21 \%$ since $2002,{ }^{34}$ and by sharply rising fuel costs. These primary factors in the inflation, the study showed, were indeed related to the Iraqi war, but were not attributable to a very large extent to Iraqi consumption or, as widely believed, Iraqis' real-estate purchases.

Prior to the Iraqi war, subsidized oil from Iraq had kept prices low. With the war, the subsidies from Iraq ended and prices rose. The rising food prices, on the other hand, prove to be largely caused by growing Jordanian food exports to Iraq. The United States Defense Department purchases large quantities of food from Jordan and uses it in Iraq to feed the US and Iraqi armed forces (the latter are also trained in Jordan, where they are housed and fed). The demand for food in Jordan, meanwhile, has increasingly been filled by imported products. That there is a growing demand for food products in Jordan is related to an extent to consumption by Iraqi residents, but the purchases of imported food, more costly for the average resident, are largely explained by the need to replace the food Jordan is exporting, and for which the United States military pays higher prices to producers than do local buyers. The study establishes its argument that the Iraqi influx has been a minor rather than a major factor in inflation by pointing to the fact that inflation in Amman where the Iraqis are settled is generally lower than in the rest of the country. In sum, the study attributes the higher costs of fuel and rising imports to be the most important factors in the painful inflation. ${ }^{35}$

Another study by the Carnegie Endowment focuses on the economic modernization and reform process underway during the 1990s. While applauding the concept, the report blames a flawed process for much of the economic distress in some sectors of Jordanian society. ${ }^{36}$ Jordanians became used to living with government subsidies for basic goods and services. The government sustained its economic support system thanks to international assistance and external resources such as remittances, oil subsidies, and trade advantages. All of these externally generated sources of income sharply declined in the 1980s. In 1989, Jordan agreed to an 
International Monetary Fund Stand-By Arrangement and its accompanying austerity program. State support for import substitution was substituted for encouragement of exports and by privatization. King Abdullah assumed office in 1999 and declared economic reform to be a priority. Yet, the Carnegie study finds the reform process to have been "selective, often incomplete and uncoordinated." 37 Business elites, entrenched political officials, and beneficiaries of the state resisted, and the reformers compromised on taxation and public sector employment. The process, according to the report, has been strongly top-down, without the engagement of Jordan's (weak) civil society. Moreover, the reform was not oriented to solving social problems or reducing poverty and unemployment. The economic reform, in short, is seen to have benefited limited sectors of Jordan's population (now able to pay for expensive realestate in Amman) and these do not include the poor or large segments of the middle class, many of whom believe their woes are the result of Iraqi refugees.

Jordan's perceived mediating role in the Arab-Israeli conflict and as a US ally in the war in Iraq have restored Jordan's place as a privileged aid recipient, both from the United States and Europe. ${ }^{38}$ It remains a preferred place for investment among Arab states as well. The Iraqis have undeniably injected valuable economic and human resources into the economy. Thus, outside resources, again, sustain the state economy but, as before, it is more vulnerable precisely because of its dependence on external resources.

\section{Syria and the Iraqis}

\section{Migration, Political and Economic Relations}

Syria and Iraq have not enjoyed smooth political relations in recent decades and tensions persist. Since the 1980s, Iraqi opponents of the regime, including dissident Sunnis, Shi'a and Christians have found refuge in Syria. Among those who found a protected safe haven were members of the current Iraqi administration, including the Prime Minister. Kurds also have come to and through Syria to reach Kurdistan. The governments of Iraq and the United States have accused the Syrian government of tacitly permitting Iraqi-bound insurgents and arms to cross through its territory after 2003. ${ }^{39}$ Syria has not denied the charge, but has not accepted official responsibility for it.

Before and after 2003, wealthy Iraqis fearing instability tended to invest and establish residences more often in Jordan than Syria, but Syria also received some of the Iraqi wealth. On the whole, the Syria-bound migrations were poorer and until recently relatively smaller. The first Iraqi wave to enter Syria following the US invasion consisted of the more politicized and politically threatened members of the Baath party, including leaders in Saddam Hussein's government and party. Iraqi Palestinians, also targeted as allied with Saddam Hussein, came as well. The fighting in Falluja in November 2004 brought a flood of Iraqis to Syria. They were still Sunni in the majority, but with that event, the flight of people escaping from the carnage far outstripped that of political leaders. ${ }^{40}$ Since then, the Shi'a predominate among the new entries. 
Syria has maintained an open border for Arab migrants since its independence.

Arabs can enter and they are entitled to avail themselves of Syrian health care and schools. They may enroll in Syrian universities, subsidized by the government, free of charge. Although they are not entitled to work, most do-or try to-and the government does not strictly enforce its own restrictions.

That the Syrian border has remained open for so long despite the huge influx of Iraqis is something of a testimonial to the strength of this tradition. ${ }^{41}$ Nevertheless, the crowding, the strains on schools and services, the traffic and the significant price increases are taxing Syrian hospitality, and public opinion has unquestionably become negative. The government has announced it will enact border restrictions, that require Iraqis to obtain visas, and the visas will be limited to people with businesses and academics. ${ }^{42}$ People are supposed to apply for visas at the Syrian Embassy in Baghdad-surely a difficult and dangerous option for many. The new restrictions, which were to be effective on September 10, 2007, were postponed to go into effect after Ramadan, on about October 12, 2007. Discussions with the government of Iraq are underway. As of this writing, the border is open, and the Iraqi flow reportedly has accelerated to take advantage of the short window of opportunity.

Syria is itself a secular and religiously diverse country. Although the majority of its citizens are Sunnis and there are influential minorities of Allowite Muslims, Shi' a, Christian, and Druze. Iraqis of almost all denominations, therefore, can find co-religionists. Nevertheless, and precisely for this reason, there are concerns that the arrival of an especially large number of Shi'a who are inclined to be devout could distort the relative sectarian harmony that characterizes Syrian society and pose potential challenges to the secular state.

\section{Numbers and Demography}

Government as well as non-government estimates converge in estimating 1.5 to 1.6 million Iraqis to be in Syria, which represents 10 percent of Syria's approximately 18 million population. As in Jordan, border guards have kept track of entries since the conflict began although not of exits or transits. Basic figures of Iraqi residents have been extrapolated from several sources which are credible but not entirely reliable. ${ }^{43}$ One diplomatic observer commented that at an April, 2007 major donor meeting held in Geneva to mobilize support for Iraqi assistance, Syrians and donors alike quoted each other's statistics with no particular justifications. All agree that Iraqi entries have been growing, especially since Jordan closed its borders. Lebanon, Egypt, Turkey, Iran and other regional outlets have taken relatively few and seem now to have closed their borders entirely to Iraq's refugees. In July 2007, UNHCR and other sources were reporting Iraqi entries into Syria at about two thousand a day, but within less than a month, these estimates were too low. ${ }^{44}$

As in Jordan, the lack of firm figures and demographic information is a problem. Syria is asking for international support in addressing the difficulties that arise from the Iraqi refugee presence, but the government can offer little hard data 
as to how many there are, or regarding their characteristics and needs. The UNDP is planning a comprehensive needs assessment based on household surveys, to be supported by the World Bank. Results are expected in about six months.

At least until recently, Iraqis came to Syria without large amounts of funds to invest. Nevertheless, of necessity, they have purchased or otherwise paid for living space, established businesses and injected money into the economy. Over the past year or so, due to the closed border in Jordan and lack of opportunities to enter other countries, more Iraqis of means are coming to Syria. They are victims of ethnic violence, forced displacement, criminality, and utter despair with conditions in Iraq.

\section{Status, Rights and Access to Assistance}

As in Jordan, Iraqis have been given three month tourist visas or permits, with the possibility of extension. In practice, there are rarely sanctions for those- the majority - who overstay and fail to renew. Contrary to the government of Jordan and the "tourist" designation status notwithstanding, the Syrian government accepts the UNHCR designation of Iraqis as prima facie refugees. In practice, the prevailing view of Iraqis in Syria and Jordan is essentially the same: they are temporarily in the country pending restoration of peace in Iraq-a peace nobody believes will occur any time soon. There are no plans for integrating the Iraqis, legally, economically or politically. The Syrians are more eager for international assistance and special programs than their Jordanian counterparts, as will be discussed below, but they intend to maintain tight oversight and control. International humanitarian assistance and its coordination will be channeled through the country's weak institutional structures.

The government allows unrestricted entry of Iraqi children to local schools, and Iraqis have the same access to health and other public services as Syrians. Those without formal status usually find badly paid employment in the informal sector, but Syrians will grant work permits to high level professionals and/or to Iraqis who establish their own businesses. The Syrian government has encouraged Iraqi scholars and scientists to establish private universities that employ Iraqi academics and teach Iraqi and Syrian students who qualify for entry. As in Jordan, the rules and procedures are neither well understood nor consistently applied, one of the consequences of which is that Iraqis are more likely than not to be without legal status in the country. ${ }^{45}$

The major appeals for education and health care described above are critically important for Syria, which has more Iraqis who are poorer and in dire need. Under an agreement with the Ministry of Health, UNHCR is already supporting 50 public health centers, and expanding the capacity of the Damascus hospital to treat cancer cases. ${ }^{46}$ Syria, like Jordan, will use the funds from the education appeal to build schools, refurbish classrooms, buy materials, etc. The government of Switzerland has funded the construction of two schools; the European Union and individual members fund small health and educational projects.

Meanwhile, living conditions are deteriorating rapidly as many Iraqis resort to 
over-crowded and unsanitary urban housing arrangements, and suffer from gradual impoverishment due to their inability to earn a living. The Syrian Arab Red Crescent carried out a Rapid Emergency Needs Assessment for the Iraqi Displacement in Syria in March 2007. The report detailed poor conditions, ever worsening, and limited access to health, housing and food. ${ }^{47}$ Although Iraqi children have the right to attend schools, UNICEF has noted that the 33,000 children who do attend school in Syria represent only about 10 percent of the total children believed to be in the country. ${ }^{48}$ The reasons range from lack of documentation, lack of funds to purchase school necessities, and the family's need for children to work.

UNHCR issues a refugee card to Iraqis upon registration. It entitles the bearers to access to health care, and special targeted assistance programs, most of which are implemented by UNHCR itself and/or by the Syrian Arab Red Crescent Society (SARC). In May 2007, a Brookings Institution-University of Bern study on Iraqis in Syria reported some 85,000 Iraqis registered; ${ }^{49}$ by August UNHCR was reporting 110,000 with the numbers of applicants growing daily. UNHCR staff conducts about 150 interviews a day, and the schedule in early August was full until the end of the following February. The process still covers only a tiny fraction of the total population, but the long lines of people standing in the sun, and the growing demand do indicate that more Iraqis are interested in registering than UNHCR currently can handle. A staff of thirty UN Volunteers works in a large registration facility (see photos) organizing appointments, conducting interviews, referring needy cases for services and identifying cases for possible resettlement. UNHCR has obtained tentative approval from the Syrian government to contract a number of international non-government agencies in order to expand its capacity, ${ }^{50}$ both for registration and service delivery. ${ }^{51}$

The NGO workers, if contracted, should effectively double the present UNHCR staff. Not only should the new recruits be able to improve the speed and efficiency of the registration process, but they will be active at the community level where UNHCR now operates small community centers able to engage in a limited number of activities. The arrangement being considered by the government, however, foresees each of the NGOs establishing individual Memorandum of Understanding with SARC, and having nearly all humanitarian assistance channeled through SARC. Even the strongest champions of SARC acknowledge that the organization is overwhelmed by the caseload it receives now, and is unprepared to handle the additional responsibilities to be thrust upon it. SARC is close to, but not part of the government, and therefore is eligible to receive direct assistance from governments not willing to fund the Syrian government. The organization will need significant resources to be able to upgrade its services and the technical capacity of its staff. Members of the International Federation of Red Cross and Red Crescent Federation are prepared to help. ${ }^{52}$ The need, however, is immediate.

Nobody denies that the Syrian government needs international assistance, least of all the Syrian government itself. On April 17, the Ministry of Foreign Affairs presented a prepared statement to a donor conference called by UNHCR and held in Geneva on "Addressing the Humanitarian Needs of the Refugees and Internally Displaced Persons in Iraq and in the Neighboring Countries." The 
statement opened as follows:

Following is a presentation of the living difficulties and the negative impact on the infrastructure in Syria due to the increasing number of Iraqi refugees. We will list the urgent humanitarian needs for 1.2 million people of Iraqi refugees, which is subject to more increase due to the continued deterioration of the security situation in Iraq (it could deteriorate due to lack of political solution and lack of security).

The paper contained a long list of burdens being borne by Syria and attributed to the Iraqi influx, and another list of requested donations and mechanisms of support in health, education, social support and security infrastructure. Syria asked the international community for US $\$ 256,810,000$ over two years, and claimed that serving Iraqi needs was costing the country a billion dollars a year. In addition to funds, Syria also asked for human resources to build its organizational capacities, especially those of SARC. ${ }^{54}$

A subsequent printed fact sheet, made available by the Syrian Embassy in Washington DC, summarized development as well as humanitarian related expenses. It calculated the costs to Syria for Iraqi consumption of natural gas, gasoline, electricity, water and sanitation, health and education and bread, all of which are subsidized by the government. The sum was just over a billion dollars.

The requests are straight forward, and the international community is sympathetic to the urgency of giving assistance, but the Syrian government has complained that the response is slower and far less generous than anticipated or deserved.5 ${ }^{55}$ Even support for SARC, at the center of Syria's humanitarian response to Iraqi refugees, has been less than anticipated. Syrians also complain that while humanitarian assistance trickles in, the more long term assistance they need to cope with the rising population is not forthcoming. The country badly needs improvements in social infrastructure, water, electricity and so on.

The donors, for their part, maintain that the process of finalizing agreements is fraught with difficulties. There is persistent and strong resistance in parts of the state apparatus to allowing foreigners to gain a foothold in Syria, and fear in some corners that humanitarian assistance could be an "Achilles heel" for this to happen. International donors who want to assist the government all complain that the approval process is long and cumbersome. Given political realities and the potential donors' distrust of the Syrian government, it is not surprising that debates over development are long and cumbersome on that side as well. Governments, like the United States which does not want to channel funds through the Syrian government at all, seek to support the Iraqi refugees by means of donations to private organizations and UN agencies, especially the UNHCR. The Bureau for Population, Refugees and Migration has given funding to the Catholic Relief Service which works with the local Syrian branch of CARITAS. For Syria, CARITAS is a local agency that long has served Syrian Christians. ${ }^{56}$ It is also funding other NGOs that primarily though not exclusively serve Christian Iraqis.

UNHCR, UNDP, UNICEF and World Food Program have found ways to work in this context. For example, UNICEF and SARC have signed a cooperation 
agreement to support women and child refugees from Iraq, beginning with support for recreational and psycho-social services ${ }^{57}$ Some of the most promising projects have been carried out at the municipal level and coordinated with municipal officials in areas where Iraqis are concentrated. These include water-sanitation, communications and environmental projects.

\section{Iraqi Impacts, Perceptions and Realities}

The strain on fragile infrastructure and services is great, especially in and around Damascus where between 80 to 90 percent of the refugee population is living. ${ }^{58}$ As numbers have grown, and people become poorer, the urban districts where the refugees are concentrated are increasingly crowded and unhealthy. By all accounts, the Syrian population has displayed kindness toward the Iraqis. However as in Jordan, people have been growing more hostile to the never-ending stream of Iraqi guests. Inevitably, the costs of housing, goods and services have risen dramatically - "skyrocketed", the residents will insist. It is hard to fathom how Iraqis or Syrians without much disposable income can afford any reasonable housing. Life has become much more costly for the average citizen, and the poorer segments of Syrian society feel themselves marginalized in their own city. Both vehicular and pedestrian traffic in Damascus is overwhelming. In summer, when this mission took place, the crush of Syrians and Iraqis was augmented by pilgrims and tourists from elsewhere in the region.

Thus far, outside of a few incidents, Iraqis have not posed a serious security threat. Nevertheless, as more Iraqis, and especially more Iraqi Shi'a, have entered, as their desperation grows and hostility toward them also increases, domestic security concerns loom larger. At an earlier stage, insurgents bound for Iraq could cross through Syrian territory, but the US military in Iraq have recently reported a sharp reduction in such crossings..$^{59}$ The Syrian government appears to have concluded that the country has a stronger interest in helping to restore peace in Iraq than in exacerbating the problems facing US occupation. At this point the government is determined to keep religious fundamentalists and political extremists from its borders. It is not clear how important the security issue was in the decision to reverse Syria's long policy of open borders - the crunch of numbers and pressures on resources are reasons enough - but surely fears of politically and religiously motivated incidents are part of the equation.

Syrian men and women, in public and in private, will affirm that the quality of their lives has been diminished by the crowding, the spiraling prices for most goods, and by a rising crime rate for the first time in memory among residents of Damascus, and they will blame it on the Iraqis. They also blame the Iraqis for spiraling rent and real estate costs. ${ }^{60}$ In these respects, the discourse in Jordan and Syria is parallel. Likewise, looking at a broader picture of costs and benefits yields a more nuanced picture in Syria, which is not dissimilar to that of Jordan.

In an interview, with the German magazine Spiegel in February 2007, the Deputy Prime Minister for Economic Affairs, Abdullah al-Dardari explained that Syria's population of 18 million had increased by 7 percent in a single year because 
of the Iraqis, and added that "no economy can simply absorb so many," In another interview on BBC radio at the end of March, he maintained that Syria would need some one billion US dollars "to deal with the inflation caused by the arrival of refugees from Iraq." 61 Nevertheless, on May 21, 2007, at a press conference in Damascus, Minister Dardari declared with pride that the Syrian economy was improving and the gross national product had risen by 7 percent in 2006 . He attributed the cause to a "surge of 16 percent in private consumption on the back of a continued influx of Iraqi refugees and of a rise in purchasing power on consumers." Investments were ahead of projections, he announced, manufacturing had sharply increased and tax receipts were also rising. Unemployment had fallen. ${ }^{62}$ At the same time, on a less positive note, the consumer price index was rising yearly to levels Syria had not seen previously.

Mr. Dardari, an economist and former journalist, has been in the vanguard of those moving toward an economic transformation in Syria, meant to result in a less corrupt and more free-market economy. His optimistic remarks find an echo in an International Monetary Fund Consultation of July 30, 2007, ${ }^{63}$ which concluded that Syria was recovering successfully from over a decade of slow growth. The IMF attributed the rebound to macroeconomic adjustment and structural reforms which compensated for regional instability, a drop in oil proceeds and pressures placed on the government by the Iraqi inflow. In fact, the report found, the recovery gained greater momentum thanks to investments from Iraqi refugees, inflationary pressures notwithstanding. The IMF applauded the government's tightening of credit policy and, it asserted, thereby reducing inflationary pressures that might otherwise have been brought on by the inevitable spike in demand due to the Iraqis.

Diplomatic observers interviewed were unanimous in noting that Syria was experiencing what one called an "economic boomlet," and that the arrival of the Iraqi had been more of a positive than a negative factor in the process. While the Iraqi-driven demand for real-estate was greater than the Syrians could accommodate, rising costs of land, rental property, construction, etc. brought profits to Syrians and boosted overall economic growth. One now sees displays of new wealth among Syrians, who appreciate the changes brought about by the country's more market based economy. Needless to say, as higher prices have spread to all sectors and credit has been tightened, Syrians with low salaries and fixed incomes have not fared well.

Two cautions that appeared in the otherwise optimistic IMF report are relevant to the Iraqi question: First, the IMF directors urged strong efforts to strengthen domestic institutional capacity and human capital, especially in management fields. Second, the report called for the government to improve the quality and timeliness of economic statistics. ${ }^{64}$ The weakness of institutional capacity, noted above, calls into question the ability of the government to use the foreign assistance and investment it badly wants in the most effective manner. The weakness of a statistical base that is all too apparent in fiscal as well as in population data leaves the government unable to plan accurately for the country's needs. The proposed UNDP/World Bank needs assessment may be a corrective.

In sum, Syrian generosity toward Iraqi refugees has brought benefits as 
well as difficulties and, for the moment, the former appear to outweigh the latter, at least insofar as the economic "bottom line" is concerned. But the benefits disproportionately go to a relatively small segment of society, much the same as they do in Jordan. The difference is that Syria is a country with a socialist ideology and, until recently, with an economically more homogeneous population. The combined effects of the economic modernization on the one hand, and the inflationary pressures partly caused by the massive Iraqi influx on the other have shifted this equation. Even if the changes are not yet dramatic, more Syrians are declining into poverty, more are involved in crime (as are Iraqis), and the spread between rich and poor is greater. The government is committed to its present economic trajectory, but is giving serious consideration to modifying some of its policies vis-à-vis the Iraqi refugees.

At this writing (October 2007) for the first time, Syria has decided to restrict the entry of Iraqis, closely following what its neighbor Jordan has done, although not closing the border altogether. The new regulations to be put in place will permit only visa holders to enter, and limit visas to specific categories, as noted above. ${ }^{65}$ It is also possible that the government could begin to limit non citizen access to currently subsidized services, such as health care, education, and water - already in short supply. In such a case, perhaps the international community would be asked to sustain the Iraqis and other non-national groups who would need assistance. To the frequently asked question as to whether the Syrian government will decide to ask UNHCR to establish refugee camps, all interviewees expressed the opinion that camps are a bad idea. Refugee camps are undesirable not only because they go against the grain ideologically, but also because establishing them would be seen as an admission that the Iraqi presence is long term. The Iraqis can be counted on to oppose such a move, even if it meant their livelihoods would be more secure. Some observers commented that if the option of establishing refugee camps is adopted, the Syrian government might strive to have these established on Iraqi territory, a step UNHCR strongly opposes.

\section{International Engagement}

All parties agree that until there is peace among the warring factions, the present pattern will persist in Iraq. Iraqis of all classes, sectors and ethnicities will be forced to flee their homes and country to seek safe refuge and means to support themselves. The governments of countries near and far have been called upon to alleviate the tragic outcomes that have fallen upon so many, but the general response has been tepid at best.

\section{Regional Response}

Beginning with Iraq itself, its government thus far has been very little engaged in supporting the refugee population, and has been widely criticized for this posture. The Iraqi government sent a fairly low level delegation to the donor Conference 
to Address the Needs of Iraqi Refugees and Internally Displaced persons, called by UNHCR on April 17-18, 2007. It made a pledge of $\$ 25$ million to assist host countries, especially with regard to health and education. The contribution is universally regarded as embarrassingly small, and doubts remain as to whether or how the funds may be delivered. The Iraqi Red Crescent attended the conference, and requested international funding for its own operations in Iraq, as well as for its expanded operations in Jordan and Syria where national Red Crescent societies are already active. At the meeting the High Commissioner Antonio Guterres stressed the importance of the Iraqi government's engagement with the population in the host countries in the interest of preventing people from being forced back into Iraq against their will. ${ }^{66}$

There may be more response from Iraq at some later date. The fact that Syria has now almost closed the border and there are no other outlets for refugees increases the pressure on the government of Iraq to do more for the growing numbers of forcibly displaced persons, now with no place to go. Iraqis outside of the country still need services of various kinds and the host governments would like to see stronger support from Iraqi embassies for these purposes.

The two exceptions to the generally tepid international response, obviously, are Syria and Jordan, the host countries described in these pages. While other "near" countries-Lebanon, Egypt, Turkey, Iran, the Gulf states-have allowed limited numbers of Iraqis to enter, none have made it easy for the Iraqis who have found their way there, and none have taken enough to constitute a burden. Syria's government officially requested the establishment of an Arab League fund to support the host countries receiving Iraqis, but it was rejected. Thus far, the wealthy Arab countries have responded minimally in terms of humanitarian assistance for the Iraqis or for support to the host countries sheltering them.

\section{International Assistance}

The donor meeting called by UNHCR in April, while not a pledging conference, provided a platform for Syria and Jordan to present the challenges that the Iraqi presence caused to their economies and institutions. The Syrian government, as noted above, presented a detailed document to this effect, while Jordan presented some indicative figures but made no specific requests. The UNHCR pledged to follow up with more effective mechanisms of international coordination and a stronger presence in Iraq itself. It asked participants for greater burden sharing, both in the form of assistance and resettlement. ${ }^{67}$

Advocates in the more developed countries are recommending that their respective governments do more for Iraqi refugees. Doing so will require serious modifications in the way donors and international agencies usually implement humanitarian projects. Because both Jordanian and Syrian governments are reluctant (to put it mildly) to permit foreign organizations to operate independently in their territories, they want projects to be channeled through national entities, preferably national government institutions. Most of the Iraqis are located in the capital cities of Amman and Damascus, and the governments understandably look 
for initiatives that benefit the local population which has been bearing the brunt of the large influx. Thus far, the largest of the international efforts thus far are the joint UNHCR-UNICEF appeal to help the educational systems in Jordan and Syria cope with the costs of absorbing Iraqi children into their school systems, and the multi agency regional health care appeal.

The international agencies are the major conduit of donor funding at this time. The UNHCR appeal for US \$60million of January 2007 was met and, in July, it was doubled to $\$ 123$ million. ${ }^{68}$ That same month UNHCR and UNICEF jointly launched the Joint Appeal for \$129 million: Providing Education Opportunities to Iraqi Children in Host Countries, described above. As of September 2007, the Iraq Situation Supplementary Appeal had received close to US\$93 million and available funds constituted $75 \%$ of budgeted expenditures. ${ }^{69}$ The education appeal is just beginning to receive pledges at this writing. The US is the principle donor, having already committed $\$ 39$ million..$^{70}$

Notwithstanding a successful mobilization of funding, the humanitarian assistance programs undertaken by UNHCR and other UN agencies-WFP, UNICEF, UNFPA - are modest, and do not have a serious impact on the increasing impoverishment of the Iraqi refugees. Where NGOs and other private sector organizations are permitted to operate, their activities currently are circumscribed and limited. Community services, legal counseling, psychosocial attention, gender related services and, especially, income generating activities are urgently needed on a much larger scale. Whether sufficient funding could be mobilized for these activities is an open question. Other refugee groups suffer similar deficiencies, although few groups are as much in the public limelight as the Iraqis. Whether and how the Jordanian or Syrian governments would support more ambitious and targeted humanitarian assistance is another issue. Income generation efforts, in particular, are sensitive because of high unemployment rates among Jordanians and Syrians. Internationally funded employment projects that reach local and refugee populations would be very costly and not necessarily politically feasible.

\section{Resettlement Prospects}

While the "far" international community sees the importance of alleviating the burden now being borne by Jordan and Syria and is disposed to assist, that assistance will not be in the form of refugee "burden sharing." No country has expressed the intention of resettling large numbers of Iraqis.

Many commentators in the press, among human rights advocates and in the US Congress have drawn parallels between the conflict in Iraq and the conflict that took place over three decades ago in Vietnam. One parallel that cannot be drawn is between the international refugee responses in the two cases. From 1975 and 1979, over 500,000 Indochinese fled the war and Communist domination..$^{71}$ They arrived in neighboring countries, which were only willing to allow them to remain temporarily in UNHCR managed camps, pending resettlement outside of the Southeast Asian region. Although the conflict in Vietnam, as the one today in Iraq, was considered to be primarily a U.S. responsibility, the governments in 
Europe, Australia and Canada, in addition to the United States-which took the lion's share-did agree to resettle the refugees. To this end, the UN organized an international conference on Indochinese refugees in July 1979 to establish multilateral commitments to burden sharing for resettlement.

The countries now willing to resettle Iraqis are among the same who have consistently responded to resettlement requests and, again, the US has proposed the largest number. The largest number in this case, however, is a few thousand which the US has promised-though not yet delivered-not several hundred thousand. Other countries are proposing to accept from a few hundred to numbers in the very low thousands The countries offering to take small numbers of Iraqis, thus far, have been the Netherlands, Sweden, Norway, Finland, Canada, Australia and New Zealand. ${ }^{72}$

To be sure, the negative comparison between responses to Iraqi and past responses to Vietnam refugees is misleading in some respects. A few qualifications are in order: First, so far as one can judge from anecdotal evidence, the majority of Iraqis in Jordan and Syria are not eager to resettle in distant countries. They, like their Jordanian and Syrian hosts, would far prefer a peaceful political arrangement that would allow them to return. Pending that return or even its absence in the short of medium term, they would prefer to see improved conditions in their host countries sufficient to permit them to live there, albeit more comfortably and with less risk. Second, unlike the countries of first asylum for the Vietnamese, neither the governments of Jordan nor Syria are pushing the Iraqis to resettle or insisting that other countries resettle them. Third, refugee authorities in resettlement countries point to the many challenges that lengthen the resettlement process. These range from the fact that they have not previously resettled large groups from the Middle East and hence have had to build the mechanisms from scratch, to the multiple security concerns that lead to extensive checks and cross checks of applicants. They predict a more robust resettlement program in the coming years.

Notwithstanding these points, the reluctance to resettle Iraqis is palpable. There would seem to be multiple reasons: the unpopularity of the war and US leadership; the fact that Iraqis on all sides are both victims and perpetrators of violence; and the fact that the massive flight was largely invisible to media and policy makers until the present year. The Iraqi flight has been gradual, family by family, not en masse. The Iraqi population settled in cities, living among the citizens of their host countries. Finally, the host countries themselves appeared to believe their institutions and resources were adequate to absorb the mass of refugees. This had changed by the end of 2006, by which time it was clear that the exodus would continue, and the new residents would stay a long time. Then, and only then, did resettlement come to be seen as an important option.

Resettlement numbers are not high enough to meet need or demand, even assuming that the majority of Iraqis are not asking for resettlement. The UNHCR registration process in Jordan, Syria and elsewhere provides the information used to recommend cases for resettlement to countries outside of the Middle East willing to take these cases. All UNHCR submissions are individuals deemed in need of resettlement. Those with a history of torture or trauma, at high risk due to membership in a political or religious minority, women at risk of violence, head 
the list of eleven criteria. One resettlement country, for example, asked for a case load consisting solely of women at risk. The nature of the case load is determined by each resettlement country, and UNHCR attempts to meet the requested numbers and qualifications. The processing itself is slow and cumbersome.

The strongest reason for low resettlement numbers among the usual resettlement countries seems to be the consensus that the US bears the greatest responsibility for Iraqi flight, hence should set a high standard, as it did for Vietnamese refugees during the 1970s and 1980s. As of early September 2007, 850 Iraqis had arrived in the US, with expectations that within a year or so, there would be some 12,000 arrivals. Interviews of refugees in Turkey, Syria, and Jordan, based primarily on UNHCR submissions, have been underway since May, and approval rates have run about 75 percent. ${ }^{73}$ The potential case load for Iraqis depends on a Presidential determination of refugee allocations. For 2007, the total allocated case load was set at 70,000, of which 50,000 were already allocated for other refugee situations, leaving 20,000 slots potentially available. Obviously, the Iraqi case load will not approach that number in 2007.

In the US, the Department of Homeland Security (DHS) staff conducts a personal interview with the members of each case UNHCR submits. Interviews in Syria are impeded by the Syrian government's present refusal to grant visas to DHS staff. Ambassador Ryan Crocker has complained to the press and Congress that only a handful of DHS officers have been sent to Jordan to conduct interviews, prolonging the process there. He suggested that at the rate interviews were proceeding, it would take nearly two years to go through the 10,000 cases UNHCR has submitted to the US. ${ }^{74}$ At his and others urging, the Department of State and Homeland Security appointed special envoys to help work though the bureaucratic delay.

Among the eleven priority criteria, the US, unsurprisingly, is particularly interested in the ninth: "individuals who fled as a result of their associations with international or foreign institutions." 75 Military and diplomatic officers deeply feel a personal responsibility to help Iraqis whose "well founded fear of persecution" is derived from having ties to the US itself. Pleas have been heard from multiple sources, from the Ambassador in Baghdad to individual commanders in the field, to expand and accelerate the processes that would allow Iraqis who have risked their lives to work with the US forces and the US government to come to the United States. First on the list of concern are Iraqis who serve as translators and, all too often, have been murdered for their service. As Senator Edward Kennedy put it, "America has a special obligation to keep faith with the Iraqis who have a bulls-eye on their back because of their association with our government."76 The difficulties arise in deciding how many will be in the program, how they will be selected and interviewed, and whether the US case load for resettlement will be entirely taken up by present or former US employees and, therefore, not include individuals falling into the remaining high priority categories. 


\section{Conclusions}

While other studies have focused on the tragic plight of Iraqis who have been forced to flee and are facing increasingly limited and difficult options, the key point of departure for this study is how the two major host countries are responding towards Iraqi refugees, and the internal logic of the response in each. Prior migration patterns, historical links and historical hostilities with Iraq have colored Jordanian and Syrian policies toward the refugees and, for very different reasons, opened the way for very large numbers of Iraqis to find a relatively safe haven. The two governments are now concerned about the long term presence of Iraqis and the possibility that the Iraqi conflict could be imported through its refugees. Governments in both countries publicly insist that they foresee an eventual return migration, and good relations with a peaceful Iraqi neighbor. However, the reality is that Iraqis and their Jordanian and Syrian hosts are facing a humanitarian crisis of longer than anticipated duration, for which there has been too little serious planning.

The impact of the Iraqi presence in the two countries thus far has been mixed There is ample evidence that Iraqis have stimulated economic vitality and helped both countries by investing in property, business and commerce. It is also apparent that the burdens of the Iraqi presence are falling most heavily on poorer segments of the population and on people with fixed incomes, who constitute the majority. Iraqis are increasingly unpopular and more often subject to abuse because of this. The governments do not wish to lose the trust of their own citizens by being seen as overly favorable to the migrants. But, neither do the governments want the economic situation of the Iraqis to deteriorate to the point of desperation.

Although current realities are not encouraging, all parties have a strong interest in a peaceful and stable Iraq. The combined efforts of regional and other international actors in this direction enhance possibilities of success, but even with the most optimistic scenario, it will take years to restore conditions in Iraq that would make a massive return movement feasible. Jordan joined the other countries of first asylum by closing its borders to Iraqis by early 2007. Having done so, the government appears somewhat more open to accommodating the Iraqis who are already in residence. Syria, the last escape route, followed suit, effective in October 2007, and plans to sharply limit Iraqi entries. This outcome is obviously tragic for Iraqis. Furthermore and also potentially tragic, neither Syria nor Jordan is granting a firm legal status, even of a temporary nature, to people already in residence, most of whom are unable to earn incomes. International support is piecemeal and thus far is inadequate to meaningfully improve the future prospects of Iraqis in Jordan and Syria or ease the burden on the host countries.

The second point of departure of this report is the response of the broader international community. The Middle East is a politically complicated area in which to launch major humanitarian and developmental initiatives. Donor governments have sought ways to avoid the difficulties of working with and channeling funding through host country governments - especially Syria-and have opted for funding international organizations which may or may not work with the governments. The funding is helpful, but does not produce coordinated, 
comprehensive assistance that both addresses humanitarian needs and national capacities. There are undeniable difficulties in terms of accountability, confidence and control in creating funding mechanisms acceptable both to the governments and the donors. These are different in Jordan and Syria, but challenging in both and not easily be surmounted. Present resettlement figures are unacceptably low, especially for the United States, but one hopes the pace will now be accelerated. At the end of the day, however, resettlement will prove to be but one tool among many, and a minor one, for solving the crisis.

Jordan and Syria's very cautious approach to international involvement thus far is understandable. There are numerous examples of international humanitarian efforts that have left governments and host populations feeling that they have lost more than they have gained. The tensions and conflicting relations that dominate Middle East political relations with the West, and with the US in particular, exacerbate distrust. Once having accepted the reality of international involvement, however, the governments can, and should, assume leadership of the process. This, in turn requires a national strategy over the long term for the Iraqi population, something that is not at all close to being in place. It also requires greater knowledge than now exists of the Iraqi population, their numbers and demographic particulars. Both Jordan and Syria have initiated steps in this direction, but have stopped before completing them.

The current system governing Iraqi legal status is based on month to month resident permits, with longer residency allotted on somewhat inconsistent rules governing investment and privileged fields of employment. Such arrangements do make some sense for a population that can move at will and is likely to remain in the country for a short time, but they are inappropriate for the Iraqis who cannot return or go elsewhere and whose needs include schools, healthy living spaces, and jobs. Nor is it in the interest either of Jordan or Syria that thousands of desperate undocumented people are kept indefinitely in legal limbo.

With the new Syrian restrictions on entry, the last open border for Iraqi refugees will be lost. It is past time for other countries in the region to open their doors more widely. Otherwise, Iraqis have much to fear from the multiple bad options facing them: lives under constant threat, vain attempts to find safer places to live in a still volatile and impoverished Iraq. The possibility of refugee camps is likely to be revisited. It remains a bad idea, and a much worse idea if the proposal is for camps inside of Iraq. Iraqis must do more to protect their citizens without resorting to this option.

The consequences of the Palestinian flight six decades ago have been fundamental in shaping attitudes toward absorption of Iraqis, and it is not a positive precedent. It is unfortunate that both countries, but especially Jordan, address the Iraq problem through the lens of the Palestinian experience. There are parallels to be sure, the most important being that Iraqis, more numerous than the original group of displaced Palestinians, could become long term residents rather than short term refugees in need of temporary Arab solidarity. But neither causes nor consequences of the respective flights are similar. Moreover, the international response mechanisms are very different today from what they were in 1948. 
There is little precedent in the Arab Middle East for absorbing refugees. As these pages describe, the frequent movements among the citizens of the region have been handled in a tolerant, but ad hoc fashion. In the face of the massive movement of Iraqis who clearly fall in the refugee category, regional decision makers appear fearful of the past Palestinian experience repeating itself and/or worried that a large Iraqi presence within their borders will exacerbate instability in their own politically sensitive political situations. These fears, combined with deep resentment against the United States for having brought Iraq to its present plight, stand in the way of a comprehensive regional analysis of the full range of possible options for Iraq, the Iraqis and regional approaches to both. 


\section{Post-script}

\section{February 2009}

There are still approximately two million Iraqis who have sought refuge in neighboring countries and the largest numbers are in Syria and Jordan. When this monograph went to press, the Syrian government had just closed its borders and Jordan's border with Iraq had been closed for the better part of a year. While certain categories of Iraqis could still enter, the process became very complicated and numbers significantly dropped. Also, but on a more positive note, the number of Iraqis fleeing violence declined as security in Iraq gradually improved in 2008.

The return movement of refugees was minimal when the monograph was published, and remained small until late in 2008. Combined, the number of returning refugees and internally displaced amounted to 220,000 in 2008 and, if improved security conditions hold, UNHCR sources predict the numbers could rise to 500,000 in 2009.

Internally Displaced Persons, IDPs, are returning at a faster rate than Iraqis who left the country. The UNHCR planning figure for January 2009 was for only 7,000 refugee returnees (UNHCR Global Appeal 2009 update). Even though security seems to be improving, people outside of the country still lack trust that it will be lasting, and say they do not yet feel safe. Moreover, difficult as the economic situation has been in Syria and Jordan, it is worse in Iraq. The Iraqi state is poorly equipped to provide basic utilities or assure access to services, jobs, and housing. Even in the best of conditions, it will take years to sort out property claims.

Conditions in Jordan and Syria remain essentially as described in these pages. The decision of Jordan's king Abdullah II to allow Iraqi children to enter both public and private schools has been a major breakthrough. Continued international support for the educational system is, of course, essential. Still, there are strains on school capacity as well as on health care, amenities, and so on. The Jordanian government has made it easier for Iraqis with financial resources to enter the country and to obtain longer term residence permits - five years renewable - but they are still expensive. The Syrian government still allows entry for fairly broad categories of people, but exerts greater control over who enters. In Syria, the schools and health facilities are, as before, open to Iraqis, but they do not have adequate capacity to meet the needs of the Iraqis or, by extension, those of Syrian citizens. In both Jordan and Syria there is growing concern that the newcomers pose security problems, are responsible for criminal activities, and are open to recruitment by extremist groups. UNHCR had registered some 400,000 refugees as of mid-2008, and has increased its assistance to educational and health care access. The Refugee Organization is also working more closely with local community groups in host countries to resolve problems.

The resettlement option for Iraqi refugees has increased. From 2007 to mid-2008, UNHCR submitted some 40,000 refugees for resettlement to 16 countries (Global Appeal 2009 update). Outside of the United States, the governments of Canada, Australia, Sweden, the United Kingdom and Germany show modest increases in admissions. The United States has increased its resettlement intake 
significantly. In FY 2008, the US admitted 13,823 Iraqis and expects to admit at least 17,000 in FY 2009.

The responses of the government of Iraq to the refugees remain ambivalent. Despite its substantial oil revenues, the Iraqi government has rarely contributed to the neighboring host countries to make refugee life there more bearable; nor has it adequately funded the institutions in Iraq that might facilitate refugee return. It is not clear how the government views refugee return in light of its preoccupation with forthcoming elections. 


\section{Endnotes}

1 Jordan is the exception. The area that had been Trans Jordan and the West Bank were united in 1950 and Palestinians on both Banks of the Jordan River were granted Jordanian citizenship. In 1988, Jordan severed its administrative and legal ties with the West Bank, but those in the east maintained Jordanian nationality. After the PLO was declared the sole representative for Palestinians in 2004, many adopted Palestinian citizenship and lost their previous Jordanian passports. By and large, Palestinians in the region, including Syria, have UNRWA Travel Documents and long-term residency documents.

2 Additionally, UNHCR in Jordan and Syria has registered a few hundred Sudanese, Somalis, Afghans and other nationalities.

3 Among these are Human Rights Watch, "The Silent Treatment"; November 2006. Refugees International Project to Asses Humanitarian Conditions in Syria and Lebanon; Ashraf al-Khalidi, Sophia Hoffmann and Victor Tanner, Iraqi Refugees in the Syrian Arab Republic: A Fieldbased Snapshot, Brookings-Bern Occasional Paper, June 2007; "Assessment on the Economic Security of the Iraqi Refugees in Syria," prepared for the ICRC, Syria, Congressional Research Service, "Iraqi Refugees and Internally Displaced Persons: A Deepening Humanitarian Crisis?", prepared by Rhoda Margesson, Jeremy Sharp and Andorra Bruno, March 23, 2007; Amnesty International, "Iraq: The Situation of Iraqi Refugees in Syria," briefing July 26, 2007; Refugees Magazine, "Regional Perspectives, Iraqi refugees in Syria, Jordan and Egypt," No. 146, Issue 2, 2007, pp.16-19; "Well off Fleeing Iraq Find Poverty and Pain in Jordan," New York Times, by Sabrina Tavernise, August 10, 2007. Shorter works are listed in the bibliography.

4 According to the report only 60 percent of the 4 million eligible for food aid receive it, down from 96 percent in 2004. Rising to the Humanitarian Challenge. July, 30, 2007. Executive Summary.

5 Ibid.; Congressional Research Service, "Iraqi Refugees and Internally Displaced Persons: A Deepening Humanitarian Crisis?" prepared by Rhoda Margesson, Jeremy Sharp, and Andorra Bruno, March 23, 2007, p.6.

6 Eleven of the fifteen southern and central governorates restrict entry and the three in the north limit entries to residents and persons sponsored by residents. IOM Press Notes, September, 7, 2007.

7 Figures are elaborated in "Iraq Displacement: 2007 Mid-year Review."

8 BBC News, August 29, 2007. Available online at: http://news.bbc.co.uk/go/pr/fr/-/2/hi/middle _ east/6968538.stm. A UNHCR press release of August 10, 2007 had estimated 50,000 leaving per month.

9 Female spouses of country nationals may eventually become citizens; for men it is more difficult.

10 Turkey has admitted Turkmen but is fearful of Kurdish entries.

11 Turkey maintains the original refugee definition, limited to Europeans; Egypt has no national refugee legislation.

12 Human Rights Watch, "The Silent Treatment" Fleeing Iraq, Surviving in Jordan, Vol. 18, No. 10(E), November 2006. p. 7.

13 UNRWA had registered just over 900,000 by 1950 . More Palestinians left after the 1967 War. 
14 In the Introduction to Palestinian Refugee Repatriation: Global Perspectives, Routledge, 2006, Michael Dumper summarizes the historical coverage and demographic of this population, see p.6.

15 Gaza residents, outside of the West Bank-Trans Jordan unification, cannot claim Jordanian nationality.

16 See Sameer Jarrah, “Amman, The City of Refugees”, Yarmuk University, 2000 (in Arabic).

17 Ibrahim Saif and David M. DeBartolo. The Iraq War's Impact on Growth and Inflation in Jordan. University of Jordan, Center for Strategic Studies. July 2007, p. 5.

18 Fafo. Study of Iraqis in Jordan. Scheduled Release: Late 2007. Available online at: http://www. fafo.no/ais/middeast/jordan/Iraqis_in_Jordan.htm.

19 Iraqis maintain that while laws encourage investment, the bureaucracies are slow and approvals may take months, causing hardships in the interim, and that Iraqi professionals are paid less than Jordanians.

20 Information summarized from the Ministry of Industry and Trade.

21 The Law on Residence and Foreigners' Affairs authorizes discretion in connection with humanitarian concerns and political asylum.

22 The extremely difficult conditions Iraqis in Jordan have been facing, and the abuses to which many have been subjected are comprehensively described in the Human Rights Watch reports, "The Silent Treatment: Fleeing Iraq and Surviving in Jordan," Vol. 18, No. 10E, November 2006; and "Iraq: From a Flood to a Trickle, Neighboring States stop Iraqis fleeing War and Persecution," No. 1, April 2007. Media both in Jordan and outside, cited in the bibliography, have been documenting the Iraqi plight as well.

23 Iraqis are often brought to Amman where educational and technical organizations, primarily from the US, and UN agencies, provide a wide variety of training, ranging from telecommunications to police work.

24 Interview, Ministry official, August 4, 2007.

25 "Providing Education Opportunities to Iraqi Children in Host Countries, A Regional Perspective," drafted July 2007.

26 Jordan Times, August 7, August 15, 2007.

27 The US pledged \$30 million during a visit to Jordan by Ellen Sauerbrey, the Assistant Secretary of State for Refugees, Population and Migration. Reported in the Jordan Times, August 23, 2007 and BBC News August 29, 2007. The US Institute for International Education (Fulbright) will support Iraqis in Jordan through a Scholar Rescue Fund in Jordan.

28 Ministry of Health interview. Note, the Ministry does not receive figures on the use of its local facilities.

29 UNHCR, "UN agencies seek US $\$ 85$ million to fund health projects for Iraqi refugees." Available online at: http://www.unhcr.org/cgi-bin/texis/vtx/iraq?page=news\&id=46f0032b2.

30 Information reported verbally in an interview of July 30, 2007 and taken from the Jordan Investment 
Board and Lands Authority websites.

31 Jordan Investment Board, Annual Report, p. 7.

32 Sufyan Alissa, "Rethinking Economic Reform in Jordan: Confronting Socioeconomic Realities", Carnegie Papers, Carnegie Endowment for International Peace, No. 4, July 2007, p. 16; interviews in Amman.

33 Ibrahim Saif and David M. DeBartolo, "The Iraq War's Impact on Growth and Inflation in Jordan," July 2007.

34 Ibid. pp. 12, 15.

35 Ibid. pp. 12-13.

36 Sufyan Alissa, "Rethinking Economic Reform in Jordan: Confronting Socioeconomic Realities", Carnegie Papers, Carnegie Endowment for International Peace, No. 4, July 2007.

37 Ibid.p. 9.

38 Jordan lost favor with the US briefly due to its refusal to take the US side in the First Gulf war.

39 Ashraf al-Khalidi, Sophia Hofmann and Victor Tanner, Iraqi Refugees in the Syrian Arab Republic: A Field-Based Snapshot, The Brookings Institution-University of Bern Project on Internal Displacement, June 2007. p. 16. "Syria's Relations with Iraq," USIP Briefing, by Mona Yacoubian. April 2007. Available online at: http://www.usip.org/pubs/usipeace_briefings/2007/ syria_iraq.pdf.

40 Ibid. pp 16-17; Interviews with Syrian journalists and intellectuals.

41 Iraqi Palestinians have not benefited from Syria's open border. Two groups, totaling over 600 are living in camps in Syria, in poor conditions and dependent on international assistance. ICRC, “Assessment on the economic Security of the Iraqi Refugees in Syria," May 10, 2007, p. 6.

42 In the first category visas may be made available to large and small business owners, so long as they are registered with formal Iraqi associations. Interview, Syrian Embassy, September 10, 2007.

43 UNHCR produced a base figure of 250,000 in 2004, derived from information from its own records, those of the World Food Program, UNICEF, and national sources.

44 Interviews in UNHCR, August 5, 7, 2007; ICRC commissioned study, May 10, 2007.

45 Ashraf al-Khalidi et. al, p. 28.

46 “UN agencies seek US\$85 million,” op cit.

47 This study was supported by the Netherlands Red Cross; see also ICRC commissioned study of May 10, 2007. See also US Conference of Catholic Bishops, "Escaping Mayhem and Murder, Iraqi Refugees in the Middle East.” Report from Mission of July, 2007.

48 Refugees International, "Iraqi Refugees: Time for the UN System to Fully Engage," July 27, 2007, prepared by Kristele Younes and Sean Garcia. Available online at: http://www.reliefweb. int/rw/rwb.nsf/db900SID/SBOI-75HS9J?OpenDocument; and "Iraqi Refugee Struggle in Syria," by Lina Sinjab, BBC News, Damascus, August 23, 2007. Available online at: http://news.bbc. co.uk/2/hi/middle_east/6956414.stm, August, 2007; Amnesty International Briefing. 
50 Norwegian Refugee Service, CARE, Save the Children-Great Britain, Danish Refugee Council, Medicins du Monde-Greece, Islamic Relief-Great Britain, Premiere Urgence-France, International Medical Committee.

51 Interviews in UNHCR and in registration center, August 4, 6, 2007.

52 ECHO plans to fund a Dutch Red Cross mission to work with and give technical assistance to SARC, but decision-making has been dragging and remains unresolved.

53 The paper was given, in English, to the researchers by a Foreign Ministry official.

54 The authors received a copy of the paper, in English, from the Department of International Organizations of the Foreign Ministry.

55 The Syrian Embassy in Washington reported total donations as of September 2007 at $\$ 2.4$ million.

56 Assyrian International News Agency, 2007. PRM gave US\$2 million for Iraqi refugees in Syria and Lebanon, most for the former. CRS also raised more than US\$1 million in private funds. The assistance is destined primarily for Iraqi Christians near Damascus and in the northern cities of Aleppo and Hasakeh, Auguest, 2007. Available online at: www.aina.org/news/20070620150048. htm.

57 August, 2007. Available online at: www.medicalnewstoday.com/articles/76548.php.

58 ICRC study, p. 7, Ashraf al-Khalidi et al, pp. 23-24. Other important Iraqi destinations are Aleppo in the Northwest, Hums and Huma, Dier az Zour and Qamisli, Hasakah and the port cities of Lataqia an Tartus.

59 General David Petraeus, as reported in a Washington Post article by Karen DeYoung, September 16, 2007, A 19.

60 Iraqis interviewed by Ashraf al Khalidi, et al in May-June contended that rents had risen three fold; the Syrian government claimed real-estate prices had risen 40 percent and rent by 150 percent. p. 30 .

61 From "The Price of Refuge" by Rania Abouzeid, Syria Today, April 2007. Available online at: http://www.syria-today.com/pkg05/index.php?page=view_article\&dir=articles\&ex $=2 \& i d=451 \&$ First $=0 \&$ Last $=13 \&$ CurrentPage $=0 \&$ src $=$ issue $\&$ cat_id $=\& i s s u e \_i d=26$.

62 "Dadari Paints a Rosy Picture of Syrian Economy," The Syria Report, May 28, 2007. Available online at: www.syria-report.com.

63 "IMF Executive Board Concludes 2007 Article IV Consultation with the Syrian Arab Republic," Public Information Notice No. 07/104, August 15, 2007. Available online at: http://www.imf.org/ external/np/sec/pn/2007/pn07104.htm, pp. 1-2.

64 Ibid. p. 3.

65 The rule went into effect on September 10, 2007, but its effects were postponed for a month.

66 "Highlights of Press Conference by UN High Commissioner for Refugees on Conference on 
Needs of Iraqi Refugees and IDPs,” UN Information Service, April 18, 2007. Document received from UNHCR.

67 Ibid.

68 Press Release, August 10, 2007. Available online at: www.unhcr.org/egi-bin/texis/vtx/ iraq?page $=$ press \&id $=46 \mathrm{bc} 9 \mathrm{c} 5 \mathrm{e} 4$.

69 Figures supplied by UNHCR. The US is the largest donor, at $\$ 36$ million, followed by Denmark at $\$ 11.6$ and Japan at $\$ 9.5$.

70 The US has been the primary donor for the UNHCR General Appeal. It has contributed $\$ 37$ million of the total \$123 requested. An additional contribution of \$20 million has gone to the ICRC; \$3.76 to the IFRC - from which the Red Crescent Societies in Jordan and Syria receive funding; and \$19 million for NGO assistance activities.

71 UNHCR, The State of the World's Refugees. Chapter 4. New York: Oxford University Press, 2000.

72 UNHCR, Resettlement of Iraqi Refugees, March 12, 2007. Available online at: http://www.unhcr. org/refworld/topic,4565c22550,4565c25f611,45fab0242,0.html.

73 Interviews Bureau of Populations, Refugees and Migration, September 11, 2007. The UNHCR submissions for the US caseload are turned over to the International Organization for Migration IOM, which organizes the case load for the US "circuit riders." IOM also receives a few direct case submissions on behalf of Iraqis employed by the US Embassy and military. See also Sabrina Tavernise and David Rohde, "Obstacles Keep Iraqi Refugees from US," New York Times, August $29,2007$.

74 "Crocker Blasts Refugee Process." By Spencer S. Hsu and Robin Wright, Washington Post, September 17, 2007.

75 UNHCR, Resettlement of Iraqi Refugees, pp. 4-5.

76 States News Service, June 19, 2007. 


\section{Bibliography}

Abouzeid, Rania. “The Price of Refuge.” Syria Today. April 2007. http://www.syria-today.com/pkg05/ index.php?page $=$ view_article $\&$ dir $=$ articles $\&$ ex $=2 \&$ id $=451 \&$ First $=0 \&$ Last $=13 \&$ CurrentPage $=0 \&$ src $=$ issue\&cat_id=\&issue_id=26. Accessed February 22, 2009.

al-Khalidi, Ashraf, Sophia Hoffmann, and Victor Tanner. Iraqi Refugees in the Syrian Arab Republic: A Field-Based Snapshot. Brookings-Bern Occasional Paper. June 2007. http://www3.brookings.edu/ fp/projects/idp/200706iraq.pdf. Accessed February 23, 2009.

Alissa, Sufyan. "Rethinking Economic Reform in Jordan: Confronting Socioeconomic Realities." Carnegie Paper. Washington: Carnegie Middle East Center, Carnegie Endowment for International Peace. July 2007.

Amnesty International. "Iraq: The situation of Iraqi refugees in Syria." An Amnesty International Briefing. July 26, 2007. http://www.amnesty.org/en/library/asset/MDE14/036/2007/en/domMDE140362007en.pdf. Accessed February 22, 2009.

Bem, Kazimierz, Nina Field, Nic Maclellan, Sarah Meyer, and Tony Morris. "A Price Too High: The Cost of Australia's Approach to Asylum Seekers.” A Just Australia, Oxfam Australia and Oxfam Novib. August 25, 2007. http://www.ajustaustralia.com/resource.php?id=215. Accessed February 23, 2009.

Bennett, Brian. "Inside the Green Zone." TIME/CNN. April 26, 2007. http://www.time.com/time/ magazine/article/0,9171,1615188,00.html. Accessed February 22, 2009.

"Catholic Relief Services Assists Iraqi Refugees in Syria, Lebanon.” Catholic Relief Services. June 20, 2007. http://crs.org/newsroom/releases/release.cfm?id=975. Accessed February 22, 2009.

Colville, Rupert. "Regional Perspectives: Iraqi Refugees in Syria, Jordan, and Egypt.” Refugees. No. 146, Issue 2, 2007. pp. 16-19. http://www.unhcr.org/publ/PUBL/4614f5802.pdf. Accessed February 24, 2009.

Congressional Research Service. Iraqi Refugees and Internally Displaced Persons: A Deepening Humanitarian Crisis?, prepared by Rhoda Margesson, Jeremy Sharp, and Andorra Bruno. March 23, 2007. http://www.fas.org/sgp/crs/mideast/RL33936.pdf. Accessed February 24, 2009.

Conseil Canadien pour les réfugiés/Canadian Council for Refugees. Backgrounder: Canada urged to Respond to Iraqi Refugees. April 16, 2007. http://www.ccrweb.ca/documents/iraqbackground07.htm. Accessed February 24, 2009.

"Dadari Paints a Rosy Picture of Syrian Economy." The Syria Report. May 28, 2007. www.syriareport.com. Accessed February 24, 2009.

DeYoung, Karen. "Fewer Foreigners Crossing Into Iraq From Syria to Fight: Drop Parallels Dip in AlQaeda Attacks." The Washington Post. September 16, 2007. http://www.washingtonpost.com/wp-dyn/ content/article/2007/09/15/AR2007091501345.html. Accessed February 24, 2009.

"Displaced Iraqis in Syria and Jordan: Relieving the Pain.” The Star (Jordan), August 2, 2007.

Dumper, Michael. Palestinian Refugee Repatriation: Global Perspectives. London: Routledge, 2006.

Fafo. Study of Iraqis in Jordan. Scheduled Release: Late 2007. http://www.fafo.no/ais/middeast/ jordan/Iraqis_in_Jordan.htm. Accessed February 24, 2009. 
Greenwell, Megan. "Nearly a third of Iraqis need emergency aid, report says." The Star (Jordan) August 2, 2007.

Hsu, Spencer S. "Envoy Urges Visas for Iraqis Aiding U.S.” The Washington Post. July 22, 2007. District Ed.: A15.

Hsu, Spencer S and Robin Wright, "Crocker Blasts Refugee Process," The Washington Post. September 17, 2007. A 01 .

Human Rights Watch. Iraq: From a Flood to a Trickle; Neighboring States Stop Iraqis Fleeing War and Persecution. April 2007. http://hrw.org/backgrounder/refugees/iraq0407/iraq0407.pdf. Accessed February 24, 2009.

Human Rights Watch. "The Silent Treatment: Fleeing Iraq, Surviving in Jordan.” Vol. 18, No. 10(E). November 2006. http://www.hrw.org/reports/2006/jordan1106/. Accessed February 24, 2009.

International Monetary Fund. "IMF Executive Board Concludes 2007 Article IV Consultation with the Syrian Arab Republic.” Public Information Notice No. 07/104. August 15, 2007. http://www.imf.org/ external/np/sec/pn/2007/pn07104.htm. Accessed February 24, 2009.

International Organization for Migration. Iraq Displacement: 2007 Mid-Year Review. July 17, 2007. http://www.iom-iraq.net/Library/2007\%20Iraq\%20Displacement\%20Mid-Year\%20Review.pdf. Accessed February 24, 2009.

Jarrah, Sameer. “Amman, The City of Refugees.” Yarmuk University, 2002 (original in Arabic).

Jordan Investment Board. Annual Report 2007. http://www.jordaninvestment.com/jibuploads/annual. pdf. Accessed February 24, 2009.

“Kennedy, Colleagues Fight to Help Iraqi Refugee Crisis.” States News Service. June 19, 2007.

“Not Fair, Not Alone.” The Jordan Times. July 31, 2007.

Oxfam America. Rising to the Humanitarian Challenge in Iraq. July 2007. http://www.oxfamamerica. org/newsandpublications/publications/briefing_papers/rising-to-the-humanitarian-challenge-in-iraq. Accessed February 24, 2009.

Oxfam Australia Community Aid Abroad and A Just Australia. "Between Iraq and a Hard Place: Iraqi refugees and asylum seekers in Australia." April 2003. http://www.ajustaustralia.com/resource. php?act=attache\&id=39. Accessed February 24, 2009.

Saif, Ibrahim and David M. DeBartolo. The Iraq War's Impact on Growth and Inflation in Jordan. Jordan: University of Jordan, Center for Strategic Studies. July 2007. http://www.jcss.org/ UploadEconomic/118.pdf. Accessed February 24, 2009.

"Sharp Rise in Iraqis Fleeing Home." BBC News. August 29, 2007. http://news.bbc.co.uk/2/hi/middle_ east/6968538.stm. Accessed February 24, 2009.

Sinjab, Lina. "Iraqi Refugee Struggle in Syria." BBC News. August 23, 2007. http://news.bbc.co.uk/2/ hi/middle_east/6956414.stm. Accessed February 24, 2009.

Spindler, William. “Are Iraqis Getting a Fair Deal?” Refugees, No. 146, Issue 2, 2007, pp. 20-23.

"Syria to Block Iraqi Refugees." Aljazeera English. September 3, 2007. http://english.aljazeera.net/ news/middleeast/2007/09/2008525123931123871.html. Accessed February 24, 2009.

“Syria to set tough visa rules for Iraqis.” Los Angeles Times. September 4, 2007. 
"Syrian Arab Red Crescent And UNICEF Agree On Humanitarian Support To Iraqi Children Refugees." Medical News Today. July 12, 2007. http://www.medicalnewstoday.com/articles/76548. php. Accessed February 24, 2009.

Syrian Arab Red Crescent (SARC). "Rapid Emergency Assessment for Iraqi Displaced in Syria." March, 2007. SARC: Damascus.

Syrian Arab Republic, Ministry of Foreign Affairs. Paper Presented by the Government of Syrian Arab Republic to the International Conference on Addressing the Humanitarian Needs of the Refugees and Internationally Displaced Persons inside Iraq and in the Neighboring Countries. Geneva: April 17, 2007.

Tavernise, Sabrina. "Well-off Fleeing Iraq Find Poverty and Pain in Jordan.” New York Times. August $10,2007$.

Tavernise, Sabrina and David Rohde. "Obstacles Keep Iraqi Refugees from US.” New York Times. August 29, 2007.

UNHCR. The State of the World's Refugees. New York: Oxford University Press, 2000.

UNHCR and UNICEF. Joint Appeal - Providing Education Opportunities to Iraqi Children in Host Countries: A Regional Perspective. July 2007. http://www.reliefweb.int/rw/RWFiles2007. nsf/FilesByRWDocUnidFilename/LSGZ-75HDKL-full_report.pdf/\$File/full_report.pdf. Accessed February 24, 2009.

UNHCR. Resettlement of Iraqi Refugees. March 12, 2007. http://www.unhcr.org/refworld/topic,4565c 22550,4565c25f611,45fab0242,0.html. Accessed February 24, 2009.

UNHCR. Supplementary Appeal, Iraq Situation Response: Protection and assistance to Iraqi Refugees in neighbouring States and to IDPs and non-Iraqi Refugees in Iraq. January 2007. http://www.unhcr. org/cgi-bin/texis/vtx/home/opendoc.pdf?tbl=SUBSITES\&id=45a4a2472. Accessed February 24, 2009.

UNHCR. "UN agencies seek US\$85 million to fund health projects for Iraqi refugees." September 18, 2007.http:/www.unhcr.org/cgi-bin/texis/vtx/iraq?page=news\&id=46f0032b2. Accessed February 24, 2009.

UNHCR, UNICEF, and World Food Programme, prepared for the ICRC. "Assessment on the Economic Security of the Iraqi Refugees in Syria.” March 2006. http://www.ncciraq.org/IMG/DRC_-_Iraqis_in_ Syria_-_March_2006.pdf. Accessed February 24, 2009.

U.S. Conference of Catholic Bishops. "Escaping Mayhem and Murder: Iraqi Refugees in the Middle East.” Mission Report 2007. http://www.usccb.org/mrs/Trip\%20Report\%20on\%20Iraqi.pdf. Accessed February 24, 2009.

United States Senate. Refugee Crisis in Iraq Act. 110th Congress, 1st Session S. 1651. June 19, 2007. http://www.govtrack.us/congress/bill.xpd?bill=s110-1651. Accessed February 24, 2009.

Yacoubian, Mona. "Syria's Relations With Iraq." USIPeace Briefing, United States Institute of Peace, Washington D.C.: April 2007. http://www.usip.org/pubs/usipeace_briefings/2007/syria_iraq.pdf. Accessed February 24, 2009.

Younes, Kristele and Sean Garcia. "Iraqi Refugees: Time for the UN System to Fully Engage." Refugees International. July 27, 2007. http://www.reliefweb.int/rw/rwb.nsf/db900SID/SBOI75HS9J?OpenDocument. Accessed February 24, 2009. 


\section{Persons who have assisted in the preparation of this report}

\section{JORDAN}

Ali M. As'Ad, Ministry of Health

Shaher Bak,National Centre for Human Rights

Yousef Daradkeh, Public Safety

David de Bartolo, Jordan Centre for Strategic Studies

Markus Geisser, ICRC (Iraq program)

Kim Gordon-Bates, ICRC, (Jordan program)

Hani Hourani, Jordan Research Center

Salem Al Khazaleh, Ministry of Industry and Trade

Imran Riza, UNHCR

Nasir Al Samaraie, ICRC

Nawaf W. Tell, Foreign Ministry

\section{QATAR}

Mashail Al Naimi, Georgetown University School of Foreign Service in Qatar Safia Al Naimi, Georgetown University School of Foreign Service in Qatar Mehran Kamrava, CIRS, Georgetown University School of Foreign Service in Qatar Kathryn King, CIRS, Georgetown University School of Foreign Service in Qatar Suzi Mirgani, CIRS, Georgetown University School of Foreign Service in Qatar

\section{SYRIA}

Fabienne Bessonne, European Union

Michael Corbin, US Embassy

Ayman Gharaibeh, UNHCR

Irénée Herbet, ICRC

Solaf Ibrahim, Foreign Ministry

Laurens Jolles, UNHCR

Nadia Jbour, UNHCR

Rana Al Madfaay, ICRC

Onfuan AL Naeb, Foreign Ministry

Helen Rask, UNHCR

Nabil Samman, Center for Research and Development

Roland Steininger, Embassy of Switzerland

Ali Al Za'tari, UNDP 


\section{USA}

Faiz Alawy, Kent State University

Richard Albright, US Department of State

William Frelick, Human Rights Watch

Dana Graber, IOM (for Iraq)

Robert Malley, International Crisis Group

Elizabeth Mercurio, Research Assistant

Khaled Sharaf, Embassy of Syria

Imad Moustapha, Ambassador, Embassy of Syria

Anne-Marie McGranaghan, UNHCR

Terry Rusch, US Department of State, PRM

Kristele Younes, Refugees International

Larry Yungk, UNHCR

Jay Zimmerman, US Department of State, PRM

Michel Gabaudan, Regional Representative UNHCR Washington, DC

Thomas Albrecht, Deputy Regional representative UNHCR Washington, DC 
Center for International and Regional Studies Georgetown University School of Foreign Service in Qatar

Education City, Qatar Foundation

P. O. Box 23689

Doha

State of Qatar

cirs.georgetown.edu

Tel +9744578400

Fax +974 4578401

Institute for the Study of International Migration

Georgetown University

Harris Building, 3300 Whitehaven Street, Third Floor

Washington, DC 20007

isim.georgetown.edu

Tel +1 2026872258

Fax +1 2026872541 